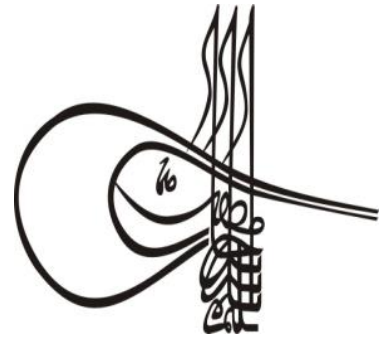

Received/Geliş: 27.05.2019

Gor Report Dates/Rapor Tarihleri: Referee 1 (28.06.2019)-Referee 2 (05.07.2019)

\section{Turkigl Studies Educational Sciences}

Volume 14 Issue 4, 2019, p. 1103-1139

DOI: 10.29228/TurkishStudies. 23274

ISSN: 2667-5609

Skopje/MACEDONIA-Ankara/TURKEY

Research Article / Araştırma Makalesi

Article Info/Makale Bilgisi

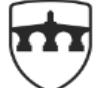

INTERNATIONAL BALKAN UNIVERSITY

EXCELLENCE FOR THE FUTURE IBU.EDU.MK

$\checkmark$ Accepted/Kabul: 10.08 .2019

This article was checked by turnitin.

\title{
TÜRKIYYE'DE OKUL ÖNCESİ ÖĞRETMENLERİ VE OKUL ÖNCESİ ÖĞRETMEN ADAYLARI İLE İLGİLI YAPILAN LİSANSÜSTÜ TEZLERİN İNCELENMESİ
}

\author{
Müzeyyen BAHÇACI ÖNAL* - Bengü TÜRKOĞLU $U^{* *}$
}

\begin{abstract}
ÖZ
$\mathrm{Bu}$ araştırmanın amac1, Türkiye'de okul öncesi öğretmen ve öğretmen adayları ile ilgili yapılmış olan lisansüstü tezlerin çeşitli değişkenlerle analizini yaparak bundan sonra yapılacak çalışmalara yeni bir bakış açısı getirebilmek, lisansüstü düzeyde araştırma eğilimlerini belirlemek ve farklı fikirlerle bu alana katkıda bulunulmasını sağlamaktır. Araştırmaya YÖK Ulusal Tez veri tabanında yer alan, onaylanan ve arşivlenen, konu bölümü "okul öncesi öğretmeni" olarak dizgilenen ve 2010-2018 yılları ile sinırlandırılan, yayınına izin verilen 120 yüksek lisans ve 16 doktora tezi olmak üzere toplam 136 lisansüstü tez dâhil edilmiştir. Tezlerin analiz edilmesinde nitel araştırma yöntemlerinden doküman incelemesi tekniği kullanılmıştır. Ayrıca tez konularının çözümlenmesinde ise içerik analizi yöntemi kullanılmıştır. Her bir tez araştırmacılar tarafından hazırlanan ve çalışmanın amacina yönelik başlıkları içeren "Tez İnceleme Formu" kullanılarak sınıflandırılmıştır. Araştırmanın verileri içerik analizi tekniği ile analiz edilmiştir. Verilerin çözümlenmesinde frekans ve yüzde dağılımlarından yararlanılmış, veriler şekiller ve tablolar üzerinde gösterilmiştir. Araştırma sonucuna göre tezlerin çoğunun yüksek lisans tezi olduğu, yıllara göre homojen bir dağılım sergilemediği, Türkçe dillinde yazıldığı, çalışma grubunun okul öncesi öğretmenleri ve öğretmen adayları olduğu, İç Anadolu Bölgesi'nde, Ankara'da ve Orta Doğu Teknik Üniversitesi'nde yürütüldüğü, proje desteği almadığı, nicel çalışmalardan oluştuğu, veri toplama aracı olarak ölçek kullanıldığı, veri analiz yöntemi olarak ANOVA (tek yönlü varyans analizi) kullanıldığı, öğretmenlerin tutum ve değerlerinin konu olarak ele alındığ tespit edilmiştir.
\end{abstract}

Öğretmen, MEB, E-posta: m.bahcaci42@hotmail.com

Dr. Öğr. Üyesi, Necmettin Erbakan Üniversitesi, E-posta: turkoglubengu @ gmail.com 
Anahtar Kelimeler: Okul öncesi öğretmeni, okul öncesi öğretmen adayı, yüksek lisans tezi, doktora tezi, araştırma eğilimi

\title{
AN OVERVIEW OF POSTGRADUATE THESES CONDUCTED ON PRESCHOOL TEACHERS AND PRESCHOOL PRE-SERVICE TEACHERS IN TURKEY
}

\begin{abstract}
The aim of this study is to analyze postgraduate theses about preschool teachers and preservice teachers in Turkey with various variables and to bring a new perspective to the studies that will be carried out in the future, to determine the research trends at the postgraduate level and to contribute to this field with different ideas. In the study, a total of 136 postgraduate theses including 120 master's and 16 doctoral dissertations, which were in the Council of Higher Education National Thesis Database and which were approved and archived by this Council, of which subject section was organized as "preschool teacher", and which were restricted to the years 2010-2018, were included. Document analysis technique which is one of the qualitative research methods was used in the analysis of theses. In addition, content analysis method was used in the analysis of thesis topics. Each thesis was classified using the "Thesis Examination Form", which was prepared by the researchers and which included the headings for the purpose of the study. Data were analyzed by content analysis technique. Frequency and percentage distributions were benefited from in the data analysis, and the data were presented on figures and tables. According to the results of the study, it was determined that most of the theses were master's theses, they were not distributed homogeneously by years, they were written in the Turkish language, the study group consisted of pre-school teachers and preschool preservice teachers, they were conducted in the Central Anatolia Region, in Ankara, and at the Middle East Technical University, they did not receive project support, they were quantitative studies, they used scales as data collection tools, ANOVA (one-way analysis of variance) was used as the data analysis method, and the attitudes and values of teachers were considered as subjects.
\end{abstract}

\section{STRUCTURED ABSTRACT}

\section{Introduction}

The concept of "preschool education" covering the education of children aged from 0 to 6 years is defined in different ways. At the 14th National Education Council (1993), preschool education was defined as a process of education that takes place within the integrity of basic education which provides rich stimuli and environmental opportunities in accordance with the developmental level and individual characteristics of children aged 0-72 months, supports their physical, mental, emotional and social development, directs them in the best way in line with the 
cultural values of the society and prepares them for primary education. According to Aral, Kandir and Can Yassar (2000), preschool education is the development and education process, which covers the years from the day the child is born to the day he/she starts primary school and takes an important place in the later life of children, in which their physical, psychomotor, social-emotional, mental and language developments are completed to a great extent and their personality is shaped by the education given. If we define preschool education in a different way, it is a planned and programmed process in which moral and cultural values are learned, which provides emotional development, develops perception capacity and problem-solving skill and also plays an important role in the development of imagination and self-expression ability (Ural \& Ramazan, 2007).

From the moment of birth, the child is involved in education, which takes places in an informal way in the family, and starts a formal process with preschool institutions within a program for all developmental characteristics. The institution that the society identifies with the concept and service of education is the school (Aç1kalın, 1998). According to Dewey (2008), there are examples of school functions such as the child's physical development, progress in reading, writing, and mathematics, increasing the knowledge of geography and history, appropriateness in attitudes and movements and development, and maturation of other habits.

After the child's family and home, the teacher is the person whom he/she is with throughout the day and he/she can get help from while meeting his/her needs. The main element of the education system is teachers, and the success of the education system is closely related to the qualifications of teachers. Effective teachers are accepted as teachers who are competent in general culture and who have both knowledge and skills related to their fields and teaching (Sen \& Erissen, 2002). The teaching profession requires teachers to be a moral model for students, rather than merely conveying certain information. The teacher also aims to bring values to new generations. However, it is very important that the teacher who will transfer these values possesses these values. At this point, rather than leaving the values that will be gained by students to the value system of the teacher, the basic guide of the teacher should be the principles of professional ethics. The principles of professional ethics are based on universal values. Therefore, regardless of a branch or teaching level, a teacher should act in accordance with ethical principles. Within the principles of professional ethics of teaching, professionalism, responsibility in service, justice, equality, ensuring a healthy and safe environment, incorruption, honesty, accuracy and trust, impartiality, professional commitment and continuous improvement, respect and effective use of resources constitute the basic framework (Aydın, 2013).

\section{Aim of the Study}

The aim of this study is to analyze postgraduate theses about preschool teachers and preservice teachers in Turkey with various variables and to bring a new perspective to the studies that will be carried out in the future and to contribute to this field with different ideas. In accordance with this aim: 
1. What is the distribution of the theses about preschool teachers and preservice teachers according to the types?

2. What is the distribution of the theses about preschool teachers and preservice teachers according to the years?

3. What is the distribution of the theses about preschool teachers and preservice teachers according to the languages?

4. What is the distribution of the theses about preschool teachers and preservice teachers according to the study groups?

5. What is the distribution of the theses about preschool teachers and preservice teachers according to the universities?

6. What is the distribution of the theses about preschool teachers and preservice teachers according to the project supports?

7. What is the distribution of the theses about preschool teachers and preservice teachers according to the research types?

8. What is the distribution of the theses about preschool teachers and preservice teachers according to the regions of the study groups?

9. What is the distribution of the theses about preschool teachers and preservice teachers according to the provinces of the study groups?

10. What is the distribution of data collection tools used in the theses about preschool teachers and preservice teachers?

11. What is the distribution of statistical methods used in the data analysis of the theses about preschool teachers and preservice teachers?

12. What is the distribution of the theses about preschool teachers and preservice teachers according to the subjects?

\section{Importance of the Study}

In the literature review, no previous document analysis studies were found on postgraduate theses, of which subject is preschool teachers and preservice teachers. In fact, it was determined that this type of study was not conducted not only on preschool teachers and preservice teachers but also on other teaching fields. It is thought that the study will bring a new perspective to the literature. In this context, various determinations and suggestions will be made to make contributions to the field.

\section{Method}

\section{Research Model}

In this study, a descriptive research design with a survey model was preferred. Descriptive research tries to describe and explain what entities, events, objects, institutions, groups, and various fields are. In this way, it is possible to understand them well and group them, and thus, the relationships between them are determined (Kaptan, 1998). In this study, postgraduate and doctoral theses conducted about preschool teachers and preservice teachers between 2010 and 2018 were analyzed and tried to be explained in terms of various variables. 


\section{Population and Sample}

Since the study aims to examine postgraduate education theses about preschool teachers and preservice teachers in Turkey, the theoretical population of the study consists of 216 postgraduate education theses, of which subject section is arranged as preschool teachers, archived by the Publication and Documentation Department of the Council of Higher Education between the years 2010-2018. The sample of the study consists of a total of 136 theses about preschool teachers and preservice teachers, including 120 postgraduate theses and 16 doctoral theses, which can be accessed in full text. The study is limited to the postgraduate theses registered in the National Thesis Center of the Council of Higher Education between the years 2010-2018 and allowed to be shared.

\section{Data Collection and Analysis}

In the study, document analysis was used as the data collection method. In the first stage of the document analysis, postgraduate theses and doctoral theses in the sample group, which could be accessed in full text from the National Thesis Center database of the Council of Higher Education, were transferred to the computer environment in pdf format. In the second stage, the theses transferred to the computer environment were analyzed according to the titles in the thesis review form created by the researcher. The thesis review form consists of the year of the thesis, the type of the thesis, the university where the thesis is conducted, the subject of the thesis, the research model, the language in which the thesis is written, the study group of the thesis, the city of the study group, the region of the study group, the data collection tool used, the statistics used in the data analysis, and the project supports received in the thesis. Frequency and percentage distributions were used in the analysis of the theses examined according to these titles. In the analysis of the thesis subjects, the content analysis method was used by taking the opinions of two experts together with the researcher. The content analysis enables the detailed analysis of data and the determination of previously unclear themes and sub-dimensions. The main purpose of content analysis is to reach the concepts and relationships that can explain the data obtained (Yıldırım \& Simşek, 2008). The final stage of data analysis is the interpretation of the findings. In this stage, in order to give meaning to the collected data and to explain the relationships between the findings, some conclusions were drawn from the findings and explanations were made in relation to the importance of the results obtained.

\section{Discussion, Conclusion, and Suggestions}

In this study, it was aimed to determine research trends by examining the postgraduate and doctoral theses carried out about preschool teachers and preservice teachers between the years 2010-2018 according to the type, subject, research type, language, study group, year, university, project support, statistical methods used in data analysis, data collection tools, provinces and regions of the study group. In line with this aim, the following conclusions were reached:

Most of the theses examined were written in the postgraduate thesis type. The reason for this situation is thought to be due to the fact that the number of universities with a postgraduate program in preschool

Turkish Studies - Educational Sciences

Volume 14 Issue 4, 2019 
education is higher than the number of universities with a doctoral program in preschool education in Turkey. Furthermore, it can be thought that the fact that the theses carried out on this subject are not allowed to be accessed by the authors in full text from the thesis database of the Council of Higher Education or that the current theses are not added to the database due to various reasons may have an effect on the higher number of postgraduate theses than the number of doctoral theses. When the studies that analyze theses in the field of education are examined, it can be observed that the number of postgraduate theses is considerably higher than the number of doctoral theses (Aydın, Selvitopu \& Kaya, 2018; Bolat, 2016; Can Yaşar \& Aral, 2014; Gürdal, Bakioğlu \& Öztuna, 2005; Kardeş, Akman \& Yazıc1, 2018; Özenç \& Özenç, 2013; Özenç \& Özenç, 2018; Şahin, Göğebakan Y1ldız \& Duman, 2011; Tatlı \& Adıgüzel, 2012; Yaşar \& Papatğa, 2015).

As a result of examining the distribution of postgraduate and doctoral theses between the years 2010-2018, it can be said that the number of theses varies between 12 and 20 according to the years, but there is no homogenous distribution increasing or decreasing according to the years. Although new postgraduate and doctoral programs are opened every year in universities and the number of students studying for postgraduate and doctoral degrees increases in line with this situation, it is thought that the lack of progressive increase in the distribution by years may be due to the fact that the subject of the study is limited to preschool teachers and preservice teachers. In the study conducted by Durukan, Atalay and SSen (2015), postgraduate theses in the field of preschool education in Turkey were examined. In this context, 340 postgraduate theses written in the last 14 years were tried to be grouped from various aspects. In line with the findings obtained in the study, it is observed that most of the theses were published in 2010 in the field of preschool education.

Most of the postgraduate and doctoral theses examined were written in Turkish. While the number of postgraduate theses written in Turkish is higher than the number of postgraduate theses written in English, the numbers of doctoral theses written in Turkish and English are very similar. It is observed that all theses written in English are the thesis studies conducted at the Middle East Technical University (Aras, 2012; Ata, 2015; Buldu, 2010; Buldu, 2016; Coşkun, 2015; Erden, 2010; Gülçiçek, 2017; Gülmez, 2012; İler, 2015; Karaduman, 2011; Özer, 2010; Özkanoğlu, 2015; Öztürk, 2010; Parlak Rakap, 2011; Sak, 2013; Sicim, 2011; Şahin 2013; Tekmen, 2012; Tezcan 2012; Y1lmaz, 2013; Y1lmaz, 2011).

In the postgraduate and doctoral theses completed between the years 2010-2018, it was determined that studies were carried out with preschool teachers, preservice preschool teachers, preschool teachers and preservice teachers, preschool teachers and parents, preschool teachers and preschoolers, preschool teachers and administrators, preschool teachers and school staff as well as academicians from the preschool education departments. It was determined that the study groups of the majority of the theses examined consisted of preschool teachers (Acar, 2016; Aktaş, 2013; Aras, 2012; Bağ, 2015; Bal, 2011; Bülbül, 2016; Ceylan, 2017; Cosskun, 2015; Dasstan, 2016; Dereli, 2013; Erden, 2010; Erkuş, 2012; Firat, 2016; Gezer, 2017; Göle, 2014; 
Gülkaya, 2016; Kadim, 2012; Kartaltepe, 2014; Orkunoğlu, 2016; Özkan, 2013; Öztürk, 2010; Sairan, 2017; Süngü, 2012; Şahin, 2013; Tepebağ, 2017; Türkdemir, 2013; Yıldırım, 2016; Y1lmaz, 2011; Zağl1, 2010; Zoroğlu, 2014) and the lowest number of studies were conducted with school staff and academicians from the preschool education departments. In general, it is observed that all stakeholders related to preschool education are included in the study.

In the theses examined, it was found out that the postgraduate theses on preschool teachers and preservice teachers were conducted in 48 different universities and the doctoral theses on preschool teachers and preservice teachers were conducted in 6 different universities. It is observed that the Middle East Technical University takes the first place with a total of 21 postgraduate and doctoral theses carried out, and Gazi University ranks second with 16 postgraduate and doctoral theses carried out. It is thought that the fact that the faculty members working in the related departments of the universities are of sufficient number and have sufficient titles, and that the sample groups can be reached more easily in the thesis studies conducted in these universities located in metropolitans are also effective in the concentration of postgraduate and doctoral theses in certain universities. There are studies supporting this finding of the study (Ahi \& K1ldan, 2013; Kardeş, Akman, \& Yazıc1, 2018).

It was determined that the theses examined did not receive project support in general, one thesis was supported within the scope of the University Scientific Research Project, and another thesis was supported within the scope of the University Scientific Research Project (SRP) and the Scientific and Technological Research Council of Turkey (TUBITAK) 1001 Program. The fact that only two theses received project support among the examined 136 theses reveals that the number of theses supported is quite insufficient. In the process of conducting postgraduate theses, receiving SRP support from their universities or TUBITAK project support in the national sense saves researchers from heavy financial burdens and paves the way for them to carry out more qualified studies with many opportunities. It is thought that researchers do not receive project support in the thesis process because they do not have sufficient knowledge about the functioning of the SRP and TUBITAK project processes, thesis advisors do not provide them with the necessary information, and they do not have the necessary conditions for project support.

Quantitative research methods were used in most of the postgraduate and doctoral theses conducted between the years 20102018, while qualitative research methods were preferred in the second place. The mixed method, which includes collecting, analyzing, and interpreting qualitative and quantitative research data in a single study or within studies and provides access to more in-depth information, was preferred in very few studies. It is thought that the quantitative method was preferred because it produces generalizable, measurable and reliable data at the level of the study population and enables the discovery of structures and patterns existing in society as a whole. Studies conducted in different disciplines reveal that quantitative research designs constitute the majority in theses. It can be said that this trend is not specific to a single field but reflects the general trend in Turkey (Baba,

Turkish Studies - Educational Sciences

Volume 14 Issue 4, 2019 
Öksüz, Çevik, \& Güven, 2011; Durukan, Atalay, \& Şen, 2015; Kardeş, Akman, \& Yazıc1, 2018; Ozan \& Köse, 2014; Öksüz, Barut, \& Dicle, 2011; Özenç \& Özenç, 2018; Tarman, Acun, \& Yüksel, 2010; Taştepe, Öztürk Serter, Yurdakul, Taygur Altıntaş, \& Bütün Ayhan, 2016; Uysal, 2013; Yaşar \& Papatğa, 2015; Yeşilyurt, 2018; Yıldız, 2004).

When the theses examined were arranged according to the provinces and regions of the study group, it was found out that the highest number of theses were conducted in the Central Anatolia Region. The Central Anatolia Region is followed by the Marmara Region in the second place and the Aegean Region in the third place. It is thought that the main point that determines the ranking of the regions is the cities. It is thought that Ankara in the Central Anatolia Region, Istanbul in the Marmara Region and Izmir in the Aegean Region allow more thesis studies to be carried out due to the fact that they are large cities with the opportunity to reach more study groups, both the existence of longestablished universities and the relatively higher number of universities compared to other cities. The studies carried out also support this research finding (Ahi \& Kildan, 2013; Yeşilyurt, 2018).

When the theses are examined according to the cities where the study groups are located, it is observed that Ankara ranks first. As can be seen in Table 2, it can be said that the reason for this situation is the thesis studies carried out at the Middle East Technical University and Gazi University. However, there are cities in which only one thesis study was conducted, such as Karaman, Batman, Tekirdağ, Muş, and Aksaray. The reason for this situation can be explained by the insufficiency of the number of faculty members in the preschool education departments of the universities in these cities and therefore the limited number of students accepted to postgraduate programs. There are studies supporting this finding (Ahi \& Kıldan, 2013; Kardeş, Akman, \& Yazıc1, 2018).

In the theses examined, it was determined that the scale was mostly used as the data collection tool and the interview was preferred the least. The use of quantitative research methods and the high availability of scales in the majority of theses explain the frequent preference of scales as a data collection tool. The fact that the interview was the least preferred data collection tool is thought to be due to the low number of theses using qualitative research methods. This finding of the study also coincides with the findings of different studies conducted in the field of education (Alper \& Gülbahar, 2009; Erdem, 2011; Kaytez \& Durualp, 2014; Seçer, Ay, Ozan, \& Y1lmaz, 2014).

When the data analysis methods of the theses are examined, it is observed that ANOVA (One-Way Analysis of Variance) takes the first place, and the t-test takes the second place. Since quantitative research techniques are mostly preferred in theses, the ANOVA and t-tests are commonly used among the parametric tests and the Kruskal-Wallis test and Mann-Whitney $U$ test are widely used among the nonparametric tests. In the theses in which qualitative research techniques are preferred, content analysis is used. The study of Ahi and Kildan (2013) supports this finding of the study.

When the subjects of the theses examined are considered, it is observed that teachers' attitudes and values are mostly discussed. The 
theme of attitudes and values is among the General Competencies of the Teaching Profession published by the General Directorate for Teacher Training and Education of the Ministry of National Education, and it includes the subheadings of national, spiritual and universal values, approach to the student, communication and cooperation, and personal and professional development. Within the framework of these subheadings, a teacher aims to observe national spiritual and universal values, to support students' development, to establish effective communication and cooperation with students, colleagues, family and other stakeholders of education, and to participate in studies aimed at personal and professional development through self-assessment. made:

According to the results of the study, the following suggestions were

- It is thought that increasing comparative thesis studies on preschool teachers and preservice teachers will contribute more to the field.

- Thesis studies conducted in the English language in the field of preschool education can be extended to other universities by not being limited to the Middle East Technical University.

- The study groups of theses to be carried out can also include children in early childhood, staff in preschool education institutions, and academicians from preschool education departments.

- In order to reach more in-depth information in thesis studies, the preference of the mixed method, in which quantitative and qualitative methods are used together, may contribute more to the field.

- Researchers can be informed in detail about these supports in order to receive more SRP and TUBITAK support for thesis studies.

- Since the number of theses conducted for scale development is insufficient, researchers can be supported to carry out studies on this subject.

Keywords: Preschool teacher, preschool preservice teacher, master's thesis, doctoral dissertations, research trend.

\section{Giriş}

Yaşamakta olduğumuz yüzyıl, problemlere çeşitli çözüm yolları üretebilen, hayal gücü yüksek ve aynı zamanda çevresine karşı duyarlı olabilen bireylere gereksinim duymaktadır. Eğitim alanında yapılan bütün projeler, yatırımlar ve etkinlikler bahsedilen özelliklerde insan yetiştirebilme amacına yöneliktir. Okul öncesi eğitimden yükseköğretime kadar olan tüm kademelerde hedef; üretken, problem çözebilen, analiz-sentez yapabilen, öz denetimi gelişmiş, kendine güveni tam olan bireyler yetiştirmektir (Parlakyıldız ve Yıldızbaş, 2004).

0 - 6 yaş dönem çocuklarının eğitimini kapsayan "okul öncesi eğitim” kavramı farklı şekillerde tanımlanmaktadır. XIV. Milli Eğitim Şurası'nda (1993) okul öncesi eğitim okul öncesi eğitimi, 0-72 ay grubundaki çocukların gelişim düzeylerine ve bireysel özelliklerine uygun, zengin uyarıcı ve çevre imkânları sağlayan, onların bedensel, zihinsel, duygusal ve sosyal yönden gelişmelerini destekleyen, kendilerini toplumun kültürel değerleri doğrultusunda en iyi biçimde yönlendiren ve ilköğretime hazırlayan, temel eğitimin bütünlüğü içerisinde yer alan bir eğitim süreci olarak tanımlanmıştır. Aral, Kandır ve Can Yaşar'a göre (2000) okul öncesi eğitim; çocuğun doğduğu günden ilkokula başladığı 
güne kadar geçen yılları kapsayan ve çocukların daha sonraki yaşamlarında önemli bir yeri olan, bedensel, psikomotor, sosyal-duygusal, zihinsel ve dil gelişimlerinin büyük ölçüde tamamlandığı, verilen eğitimle kişiliğin şekillendiği gelişim ve eğitim sürecidir. Okul öncesi eğitimi daha farklı olarak tanımlarsak, ahlaki ve kültürel değerlerin öğrenildiği, duygu gelişimi, algılama kapasitesi ve problem çözme yeteneğini geliştiren ayrıca hayal gücünün gelişmesinde ve kendini ifade kabiliyetini edinmesinde önemli rol oynayan, planlı ve programlı bir süreçtir (Ural ve Ramazan, 2007).

İnsanoğlunun hayatı göz önüne alındığında bazı dönemler psikolojik ve fizyolojik açıdan kritik dönemlerdir. 0-6 yaş arasını kapsayan, okul öncesi dönem olarak adlandırılan yıllar da bireyin kişiliğinin oluşumu ve şekillenmesi, temel bilgi ve becerilerin kazanılması ve ilerletilmesi açısından en kritik dönemlerden biridir (Arı, 2003). Beyin okul öncesi dönem boyunca hızlı geliştiği için bu dönem, beynin çevresel etkilere en açık olduğu dönemdir. Bu kapsamda çevre, çocuğun gelişimini ve öğrenme motivasyonunu derinden etkiler. Çocuğun ne kadar keşfedebileceği, neler öğrenebileceği ve hangi hızla öğrenebileceği çocuğun çevresinin ne kadar destekleyici olduğuyla ve çocuğa ne gibi olanaklar sunulduğuyla yakından ilişkilidir. Çevresel etkiler çocuğun beyin gelişimini olumlu yönde etkileyebileceği gibi, olumsuz çevre koşullarına bağlı olarak istenmeyen bir şekilde de etkileyebilir. Çocuğun sağliklı bir beyin gelişimine sahip olabilmesi için okul öncesi dönem boyunca sağlıklı beslenmesi, zengin uyarıcı bir çevre içinde bulunması ve çocuğa yeni öğrenme firsatlarının sunulması gerekmektedir. Çevre, uyaranlar bakımından ne kadar zengin olursa çocuk o kadar hızlı gelişir ve öğrenir. Ancak çocuğun ilk yıllarını uyaranların yetersiz olduğu, duygusal ve fiziksel desteğin yeterince sunulmadığı ve yeni öğrenme firsatlarının yaratılmadığı bir çevrede geçirmesi çocuğun beyin gelişimini olumsuz etkiler (MEB, 2013).

Çocuk doğduğu andan itibaren bir eğitimin içindedir, bu eğitimi aile içinde informal bir şekilde gerçekleştirirken, bütün gelişim özelliklerine yönelik bir program dâhilinde formal bir sürece okul öncesi kurumlarıyla adım atar. Toplumun eğitim kavramı ve hizmeti ile özdeşleştirdiği kurum, okuldur (Açıkalın, 1998). Dewey’e göre (2008) okulun işlevleriyle ilgili olarak, çocuğun bedensel gelişiminin yolunda gitmesi; okumada, yazmada, matematikte ilerlemesi, coğrafya ve tarih bilgisinin artması, tavır ve hareketleri, gelişiminde düzgünlük ve diğer alışkanlıklarının olgunlaşması gibi örnekler sayılabilir.

Çocuğun ailesinden ve evinden sonra, gün boyu birlikte olduğu ihtiyaçlarını karşılarken gerektiğinde yardım alabileceği kişi öğretmendir. Okul öncesi eğitim kurumlarında öğretmenle çocuk arasında sevgi ve güvene dayalı bir iletişim olduğunda evden ilk defa uzaklaşan çocuk öğretmenini annesi ile özdeşleştirir. Bu anlamda öğretmenin aileyi de tanıması ve aile ile işbirliği yapması çocuğun sağlıklı gelişimi açısından çok önemlidir. Çeşitli ülkelerin eğitim sistemleri ne bakıldığında sistemin yapısı ne olursa olsun, bu sistemlerdeki en önemli ögelerin öğretmen, eğitim programı ve öğrenci olduğu görülmektedir. Öğrenci ögesi, sistemin hem girdisi hem çıktısı olarak; eğitim programı, okul içi ve okul dışındaki öğretme ve öğrenme etkinliklerinin bütünü olarak; öğretmen ögesi ise, hem sürecin, hem de çıktının kalite güvencesi olarak görülmektedir (Gürkan, 2005).

Eğitim sisteminin en temel ögesi öğretmenlerdir ve eğitim sisteminin başarısı öğretmenlerin sahip oldukları nitelikler ile yakından ilgilidir. Etkili öğretmenler genel kültür açısından yeterli, hem alanları hem de öğretmenlik ile ilgili bilgi ve becerilere sahip öğretmenler olarak kabul edilmektedir (Şen ve Erişen, 2002). Öğretmenlik mesleği sadece belli başlı bilgilerin aktarılmasından ziyade, öğrencilere ahlaki yönden de tam bir model olmayı gerektirir. Öğretmen aynı zamanda yeni nesillere değerler kazandırılmasını da amaçlar. Fakat bu değerleri aktaracak olan öğretmenin de bu değerlere sahip olması son derece önemlidir. Bu noktada öğrenciye kazandırılacak değerleri öğretmenin değer sistemine bırakmaktan ziyade öğretmenin temel kılavuzu, mesleki etik ilkeleri olmalıdır. Mesleki etik ilkeler evrensel değerler üzerine kuruludur. Bu sebeple branş1 veya öğretim düzeyi ne olursa olsun bir öğretmenin etik ilkeler doğrultusunda hareket etmelidir. Öğretmenlik meslek etiği ilkeleri içerisinde profesyonellik, hizmette sorumluluk, adalet, eşitlik, sağlıklı ve güvenli bir ortamın sağlanması, 
yolsuzluk yapmamak, dürüstlük, doğruluk ve güven, tarafsızlık, mesleki bağl1lık ve sürekli gelişme, saygı ve kaynakların etkili kullanımı gibi ilkeler temel çerçeveyi oluşturmaktadır (Aydın, 2013).

Okul öncesi eğitim kurumlarında çocukların eğitimlerinden sorumlu kişiler okul öncesi öğretmenleridir. Okul öncesi öğretmenlik uygulamaları diğer öğretmenlik uygulamalarından farklıdır. Okul öncesi eğitimin kendine özgü süreçleri vardır; eğitim ortamının düzenlenmesi ile birlikte hedefler, öğrenme-öğretme faaliyetleri ve değerlendirme süreci bunların içinde yer alır. Okul öncesi eğitiminde çok sayıda olay, durum aynı anda ve hızlı bir şekilde gerçekleşir. Okul öncesi öğretmeni, bütün bunları aynı anda izleyip yönetmekle sorumludur. Gün içerisinde ani karşılaştığı durumlarla ilgili kararlar almak zorundadır. Buna bağlı olarak okul öncesi öğretmenliğinde hızlı bir tempo vardır. Ayrıca okul öncesi öğretmenliğinde, öğretmenin eğitim sürecinde edindiği teorik bilgileri, geçmiş deneyimleriyle, duygularıyla, öngörüleriyle ve kendi iç kaynaklarıyla harmanlaması, çocukların ailelerinden bilgi alması ve meslektaşları ile bilgi paylaşımı yapması gerekmektedir (Şahin, 2005). Okul öncesi eğitimi programında okul öncesi eğitimde etik davranışlar ve meslek etiğine yönelik sorumluluklardan bahsedilmiştir (MEB, 2006). Fakat güncellenen okul öncesi eğitimi programında, meslek etiğine yönelik herhangi bir açılama bulunmamaktadır (MEB, 2013).

Milli Eğitim Bakanlığı (2017a, 2017b), öğretmen yeterliğini, öğretmenlerin "öğretmenlik mesleğini etkili ve verimli biçimde yerine getirebilmek için sahip olması gereken bilgi, beceri ve tutumlar" olarak tanımlanmaktadır. Eğitim alanında belirlenen hedeflere ulaşabilmek, bu sürece yön veren öğretmenlerin nitelik ve yeterlilikleriyle yakından ilişkilidir. Öğretmenin temel yeterliliklere sahip olması öğrencilerin başarılarını artırmanın kişisel gelişimlerini sağlamalarının anahtarlarından biridir. Öğretmenlerde aranan nitelik ve yeterliklerin belirlenmesi, ülkemizde Milli Eğitim Bakanlığı tarafından yapılmaktadır. 1739 sayılı Milli Eğitim Temel Kanunu'nda öğretmenliğin bir "ihtisas mesleği” olduğu vurgulanmaktadır. Yine bu kanunun 45. maddesinde "Öğretmen adaylarında genel kültür, özel alan eğitimi ve pedagojik formasyon bakımından aranacak nitelikler Milli Eğitim Bakanlığınca tespit olunur." ifadesine yer verilmektedir (MEB, 1973). 652 sayılı Milli Eğitim Bakanlığı'nın Teşkilat ve Görevleri Hakkında kanun Hükmünde Kararname'nin 15.maddesinin (a) fikrası gereği öğretmen nitelik ve yeterliklerin belirlenmesi görevi Öğretmen Yetiştirme Genel Müdürlüğü'ne verilmiştir. Bu fikraya göre Öğretmen yetiştirme Genel Müdürlügünden "Öğretmenlerin nitelikleri ve yeterliklerin belirlenmesi ve geliştirilmesine yönelik politikaları oluşturması, bu amaçla ilgili birim kurum ve kuruluşlarla işbirliği yapması" beklenmektedir (Resmi Gazete, 2011). Yeterlik güncelleme çalışmaları sürecinde her bir öğretmenlik alanı için ayrı bir özel alan yeterliği belirlemek yerine, genel yeterliklere alan bilgisi ve alan eğitimi bilgisi yeterlikleri eklenmiş, böylece her bir öğretmenin kendi alanına ilişkin yeterliklerini de kapsayacak mahiyette bütünsel ve tek bir metin oluşturulmuştur. Bu kapsamda güncellenen Öğretmenlik Mesleği Genel Yeterlikleri; "mesleki bilgi”, "mesleki beceri”, tutum ve değerler" olmak üzere birbiriyle ilişkili ve birbirini tamamlayan 3 yeterlik alanı ile bunlar altında yer alan 11 yeterlik ve bu yeterliklere ilişkin 65 göstergeden oluşmaktadır. Söz konusu yeterlik alanları ve bu alanlar içerisinde yer alan genel yeterlikler Şekil 1'de yer almaktadır (MEB, 2017b). 


\begin{tabular}{|c|c|c|c|c|c|}
\hline $\mathbf{A}$ & Mesleki Bilgi & $\mathbf{B}$ & Mesleki Beceri & C & Tutum ve Değerler \\
\hline \multirow[t]{2}{*}{ A1. } & Alan Bilgisi & B1. & Egitim Ögretimi Planlama & C1. & $\begin{array}{l}\text { Milli, Manevi ve Evrensel } \\
\text { Degerler }\end{array}$ \\
\hline & $\begin{array}{l}\text { Alanında sorgulayıcı bakış } \\
\text { açısını kapsayacak șekilde } \\
\text { ileri düzeyde kuramsal, } \\
\text { metodolojik ve olgusal } \\
\text { bilgiye sahiptir. }\end{array}$ & & $\begin{array}{l}\text { Eḡitim og gretim süreçlerini etkin } \\
\text { bir șekilde planlar. }\end{array}$ & & $\begin{array}{l}\text { Milli, manevi ve evrensel } \\
\text { değerleri gözetir. }\end{array}$ \\
\hline \multirow[t]{2}{*}{ A2. } & Alan Egitimi Bilgisi & B2. & $\begin{array}{l}\text { Ögrenme Ortamlan } \\
\text { Olusturma }\end{array}$ & $\mathrm{C} 2$ & Ögrenciye Yaklaşım \\
\hline & $\begin{array}{l}\text { Alanunu ögrretim programma } \\
\text { ve pedagojik alan bilgisine } \\
\text { hâkimdir. }\end{array}$ & & $\begin{array}{l}\text { Bütün öğrenciler için etkili } \\
\text { ögrenmenin gerçekleşebileceği } \\
\text { sağlıklı ve guvivenli oğrenme } \\
\text { ortamları ile uygun ögretim } \\
\text { materyalleri hazırlar. }\end{array}$ & & $\begin{array}{l}\text { Ōgrencilerin gelişimini } \\
\text { destekleyici tutum sergiler. }\end{array}$ \\
\hline \multirow[t]{4}{*}{ A3. } & Mevzuat Bilgisi & B3. & $\begin{array}{l}\text { Ögretme ve Ögrenme } \\
\text { Sürecini Yönetme }\end{array}$ & C3. & İetisim ve İs Birligi \\
\hline & \multirow{3}{*}{$\begin{array}{l}\text { Birey ve öğretmen olarak } \\
\text { görev, hak ve } \\
\text { sorumluluklarna ilişsin } \\
\text { mevzuata uygun davranır. }\end{array}$} & & $\begin{array}{l}\text { Ogrretme ve öğrenme sürecini } \\
\text { etkili bir şekilde yüritüur. }\end{array}$ & & $\begin{array}{l}\text { Öğrenci, meslektass, aile ve } \\
\text { eğitimin diğer paydaşlan ile } \\
\text { etkili iletişim ve iş birliği } \\
\text { kurar. }\end{array}$ \\
\hline & & B4. & Ölçme ve Degerlendirme & C4. & $\begin{array}{l}\text { Kişisel ve Mesleki } \\
\text { Gelisim }\end{array}$ \\
\hline & & & $\begin{array}{l}\text { Ölçme ve değerlendirme, } \\
\text { yőtem, teknik ve araçlarmı } \\
\text { amacına uygun kullanir. }\end{array}$ & & $\begin{array}{l}\text { Öz değerlendirme yaparak, } \\
\text { kişisel ve mesleki gelisiminine } \\
\text { yönelik çalışmalara katılır. }\end{array}$ \\
\hline
\end{tabular}

Şekil 1: Öğretmenlik Mesleği Genel Yeterlikleri

Milli Eğitim Bakanlığı'nın yayınladığının çalışmada okul öncesi öğretmeni özel alan yeterlikleri aşağıdaki yeterlik alanları ve yeterliklerden oluşmaktadır (MEB, 2017b);

1) Gelişim Alanları

a) Gelişim alanlarını desteklemek için eğitim sürecini planlayabilme

b) Eğitim ortamını düzenleyebilme

c) Materyal seçebilme, kullanabilme ve hazırlayabilme

d) Eğitim faaliyetlerini yürütebilme

2) Ailelerle İletişim, Aile Katılımı ve Aile Eğitimi

a) Ailelerle iletişim kurabilme ve aile katılımını sağlayabilme

b) Aile eğitimi etkinliklerini yürütebilme

3) Değerlendirme

a) Eğitim programını değerlendirebilme

b) Çocukların gelişimini değerlendirebilme

4) İletişim

a) Etkin dinleme becerisini geliştirebilme

b) Empati kurabilme becerisini geliştirebilme

c) Kendini söz, beden ve sanat yoluyla ifade edebilme becerisini geliştirebilme

d) Bilişim teknolojilerinin günlük yaşamda kullanımına ait farkındalık geliştirebilme

5) Yaratıcılık ve Estetik

a) Araştırma, keşfetme ve alternatif çözüm yolları üretme becerisini geliştirebilme

b) Özgün ürünler oluşturma becerisini geliştirebilme

c) Estetik anlayışı ve seçicilik becerilerini geliştirebilme

6) Okul ve Toplumla İşbirliği Yapma

Turkish Studies - Educational Sciences

Volume 14 Issue 4, 2019 
a) Çocukların, ulusal bayram ve törenlerin anlam ve öneminin farkına varmalarını ve katılımlarını sağlayabilme

b) Ulusal bayram ve törenlerin yönetim ve organizasyonunu yapabilme

c) Okulun kültür ve öğrenme merkezi haline getirilmesinde toplumla işbirliği yapabilme

7) Mesleki Gelişimi Sağlama

a) Mesleki gelişimini belirleyebilme

Araştırmanın Amacı

Bu araştırmanın amac1, Türkiye'de okul öncesi öğretmen ve öğretmen adayları ile ilgili yapılmış olan lisansüstü tezlerin çeşitli değişkenlerle analizini yaparak bundan sonra yapılacak çalışmalara yeni bir bakış açısı getirebilmek ve farklı fikirlerle bu alana katkıda bulunulmasını sağlamaktır. Bu amaç doğrultusunda;

1. Okul öncesi öğretmen ve öğretmen adayları ile ilgili yapılan tezlerin türüne göre dağılımı nasildır?

2. Okul öncesi öğretmen ve öğretmen adayları ile ilgili yapılan tezlerin yılına göre dağılımı nasıldir?

3. Okul öncesi öğretmen ve öğretmen adayları ile ilgili yapılan tezlerin yazıldığı dile göre dağılımı nasildir?

4. Okul öncesi öğretmen ve öğretmen adayları ile ilgili yapılan tezlerin çalışma grubuna göre dağılımı nasıldır?

5. Okul öncesi öğretmen ve öğretmen adayları ile ilgili yapılan tezlerin yürütüldüğü üniversitelere göre dağılımı nasıldır?

6. Okul öncesi öğretmen ve öğretmen adayları ile ilgili yapılan tezlerin proje desteği almasına göre dağılımı nasıldır?

7. Okul öncesi öğretmen ve öğretmen adayları ile ilgili yapılan tezlerin araştırma türlerine göre dağılımı nasıldır?

8. Okul öncesi öğretmen ve öğretmen adayları ile ilgili yapılan tezlerin çalışma gruplarının bölgelere göre dağılımı nasıldır?

9. Okul öncesi öğretmen ve öğretmen adayları ile ilgili yapılan tezlerin çalışma gruplarının illere göre dağılımı nasıldır?

10. Okul öncesi öğretmen ve öğretmen adayları ile ilgili yapılan tezlerde kullanılan veri toplama araçlarının dağılımı nasıldır?

11. Okul öncesi öğretmen ve öğretmen adayları ile ilgili yapılan tezlerin veri analizinde kullanılan istatistiksel yöntemlerin dağılımı nasıldır?

12. Okul öncesi öğretmen ve öğretmen adayları ile ilgili yapılan tezlerin konularına göre dağılımı nasildır?

\section{Araştırmanın Önemi}

Alan yazın taramasında konusu okul öncesi öğretmen ve öğretmen adayları olan lisansüstü tezlere yönelik daha önce yapılan herhangi bir doküman analizi çalışmasına rastlanmamıştır. Hatta sadece okul öncesi öğretmen ve öğretmen adayları ile ilgili değil, diğer öğretmenlik alanları ile ilgili de bu türde bir çalışma yapılmadığı tespit edilmiştir. Çalışmanın alan yazına yeni bir bakış açısı kazandıracağı düşünülmektedir. Bu bağlamda alana katkı sağlamak için çeşitli tespitlerde ve önerilerde bulunulacaktır. 


\section{Yöntem}

$\mathrm{Bu}$ bölümde araştırmanın amacına ulaşmak için kullanılan; araştırmanın modeli, evren ve örneklem, verilerin toplanması ve analiz edilmesine yer verilmiştir.

\section{Araştırma Modeli}

$\mathrm{Bu}$ araştırmada tarama modelinde betimsel araştırma deseni tercih edilmiştir. Betimsel araştırmalar; varlıkların, olayların, objelerin, kurumların, grupların ve çeşitli alanların ne olduğunu betimlemeye, açıklamaya çalışır. Bu şekilde onları iyi anlayabilme ve gruplayabilme olanağı sağlanır; aralarındaki ilişkiler saptanmış olur (Kaptan, 1998). Yapılan bu çalışmada da 2010 - 2018 yılları arasında okul öncesi öğretmen ve öğretmen adayları ile ilgili yapılmış olan yüksek lisans ve doktora tezleri çeşitli değişkenler açısından analiz edilerek açıklanmaya çalışılmıştır.

\section{Evren ve Örneklem}

Araştırmada, Türkiye'de okul öncesi öğretmen ve öğretmen adayları ile ilgili yapılmış lisansüstü eğitim tezlerinin incelenmesi amaçlandığından araştırmanın kuramsal evreni, YÖK Yayın Dokümantasyon Daire Başkanlığı tarafından 2010-2018 yılları arasında arşivlenen, konu bölümü okul öncesi öğretmen olarak dizgilenen 216 lisansüstü eğitim tezinden oluşmaktadır. Araştırmanın örneklemi ise okul öncesi öğretmen ve öğretmen adayları ile ilgili yapılmış ve tam metin olarak ulaşılabilen 120 yüksek lisans ve 16 doktora tezi olmak üzere toplam 136 tezden oluşmuştur. Araştırma, Yüksek Öğretim Kurulu Ulusal Tez Merkezi'ne 2010-2018 yıllarında kaydedilen ve paylaşımına izin verilen lisansüstü eğitim tezleri ile sinırlıdır.

\section{Verilerin Toplanması ve Analizi}

Araştırmada veri toplama yöntemi olarak doküman analizi kullanılmıştır. Doküman analizinin birinci aşamasında YÖK Ulusal Tez veri tabanından tam metin olarak ulaş1labilen, örneklem grubunda yer alan yüksek lisans ve doktora tezleri pdf formatında bilgisayar ortamına aktarılmıştır. İkinci aşamada ise, bilgisayar ortamına aktarılan tezler, araştırmacı tarafından oluşturulan Tez inceleme formundaki başlıklara göre çözümlenmiştir. Tez inceleme formu; tezin yıll, tezin türü, tezin yürütüldüğü üniversite, tezin konusu, araştırma modeli, tezin yazıldığı dil, tezin çalışma grubu, tezin çalışma grubundaki şehir, tezin çalışma grubundaki bölge, kullanılan veri toplama aracı, veri analizinde kullanılan istatistikler, tezin proje desteği alma durumu başlıklarından oluşmaktadır. Bu başlıklara göre incelenen tezlerin çözümlenmesinde frekans ve yüzde dağılımları kullanılmıştır. Tez konularının çözümlenmesinde ise araştırmacı ile beraber alanında uzman iki kişinin görüşleri alınarak içerik analizi yöntemi kullanılmıştır. İçerik analizi, verilerin detaylı analizini ve önceden belirgin olmayan tema ve alt boyutların ortaya çıkarılmasını olanaklı kılar. İçerik analizindeki temel amaç, elde edilen verileri açıklayabilecek kavramlara ve ilişkilere ulaşmaktır (Yıldırım ve Şimşek, 2008). Verilerin çözümlenmesinin son aşaması ise bulguların yorumlanması aşamasıdır. Bu aşamada toplanan verilere anlam kazandırmak ve bulgular arasındaki ilişkileri açıklamak, bulgulardan bir takım sonuçlar çıkarmak ve elde edilen sonuçların önemine ilişkin açıklamalar yapılmıştır.

\section{Bulgular}

2010-2018 yılları arasında okul öncesi öğretmen ve öğretmen adayları ile ilgili yapılan yüksek lisans ve doktora tezlerinin incelenmesi sonucunda aşağıdaki bulgular elde edilmiştir. Elde edilen bulgular şekil ve tablolar halinde sunulmuştur: 


\section{Okul Öncesi Öğretmen Ve Öğretmen Adayları İle İlgili Yapılan Tezlerin Türlerine İlişkin Bulgular}

Şekil 2'den de anlaşılacağ yüksek lisans ve doktora tezlerinden incelenen 136 tezin 120'sinin (\% 88,2) yüksek lisans tezi, 16 'sının (\% 11,8) doktora tezi olduğu görülmüştür.

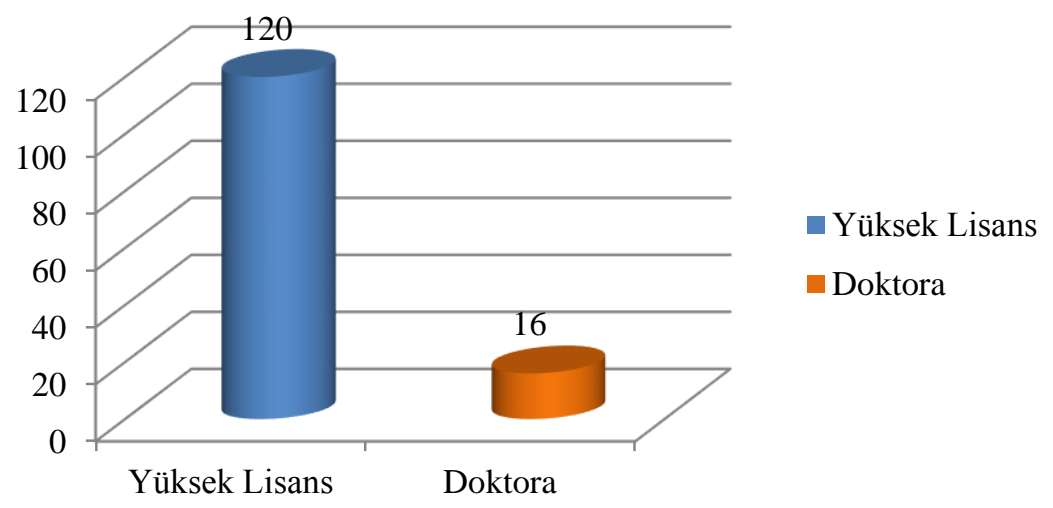

Şekil 2. Tezlerin Türüne Göre Dağılımı

\section{Okul Öncesi Öğretmen Ve Öğretmen Adayları İle İlgili Yapılan Tezlerin Yıllara Göre Dağılımına İlişkin Bulgular}

Tablo 1'den de anlaşılacağı üzere, incelenen tezlerin 19'u (\% 14) 2010 yılında, 12'si (\% 8,8) 2011 yılında, 16's1 (\% 11,7) 2012 y1lında, 20'si (\% 14,7) 2013 yılında, 16’s1 (\% 11,7) 2014 y1lında, 16's1 (\% 11,7) 2015 yılında, 20'si (\% 14,7) 2016 yılında, 15'i (\% 11) 2017 yılında yazılmıştır. 2018 yılında okul öncesi öğretmen ve öğretmen adayları ile ilgili yapılmış bir tez alan yazında bulunamamıştır.

Tablo 1: Tezlerin Yıllara Göre Dağılımı

\begin{tabular}{lcccccc}
\hline \multirow{2}{*}{ Yıllar } & \multicolumn{2}{c}{ Yüksek Lisans } & \multicolumn{2}{c}{ Doktora } & \multicolumn{2}{c}{ Toplam } \\
\cline { 2 - 7 } & f & $\mathbf{\%}$ & f & \% & f & \% \\
\hline 2010 & 18 & 15 & 1 & 6,2 & 19 & 14 \\
\hline 2011 & 11 & 9,1 & 1 & 6,2 & 12 & 8,8 \\
\hline 2012 & 12 & 10 & 4 & 25 & 16 & 11,7 \\
\hline 2013 & 17 & 14,2 & 3 & 18,7 & 20 & 14,7 \\
\hline 2014 & 15 & 12,5 & 1 & 6,2 & 16 & 11,7 \\
\hline 2015 & 14 & 11,7 & 2 & 12,5 & 16 & 11,7 \\
\hline 2016 & 19 & 15,8 & 1 & 6,2 & 20 & 14,7 \\
\hline 2017 & 13 & 10,8 & 2 & 12,5 & 15 & 11 \\
\hline
\end{tabular}

3. Okul Öncesi Öğretmen Ve Öğretmen Adayları İle İlgili Yapılan Tezlerin Yazıldığı Dile Göre Dağılımına İlişkin Bulgular

Şekil 3'den de anlaşılacağı üzere, incelenen tezlerin 106'sı (\% 88,3) yüksek lisans, 9'u (\% 56,3) doktora olmak üzere toplam 115'i (\% 84,5) Türkçe; 14'ü (\% 11,7) yüksek lisans, 7'si (\% 43,7) doktora olmak üzere toplam 21'i $(\%$ 15,4) İngilizce olarak yazılmıştır. 


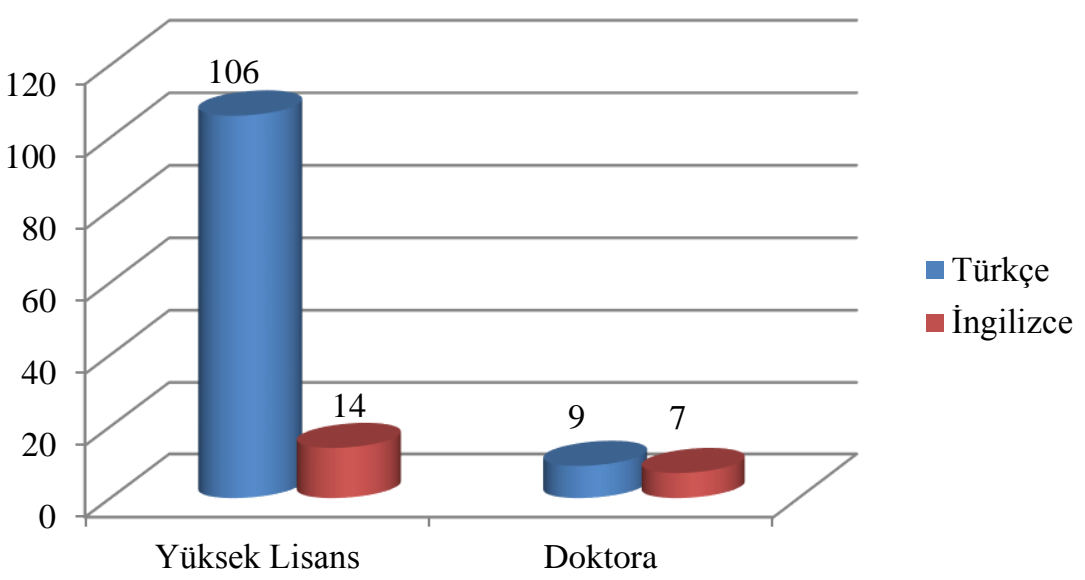

Şekil 3: Tezlerin Yazıldı̆̆ı Dile Göre Dağılımı

\section{Okul Öncesi Öğretmen Ve Öğretmen Adayları İle İlgili Yapılan Tezlerin Çalışma Grubuna Göre Dağılımına İlişskin Bulgular}

Şekil 4'den de anlaşılacağı üzere, incelenen tezlerin 97'si (\% 71,3) okul öncesi öğretmenleriyle, 20'si (\% 14,7) okul öncesi öğretmen adaylarıyla, 5’i (\% 3,7) okul öncesi öğretmenleri ve öğretmen adaylarıyla, 5'i (\% 3,7) okul öncesi öğretmenleri ve ebeveynlerle, 3'ü (\% 2,2) okul öncesi öğretmenleri ve okul öncesi dönem çocuklarıyla, 2'si (\% 1,5) okul öncesi öğretmenleri ve yöneticileriyle, 1 'i $(\% 0,7)$ okul öncesi öğretmenleri ve okul personeliyle ve 1 'i $(\% \quad 0,7)$ okul öncesi öğretmenliği bölümü akademisyenleri ile çalışılmıştır.

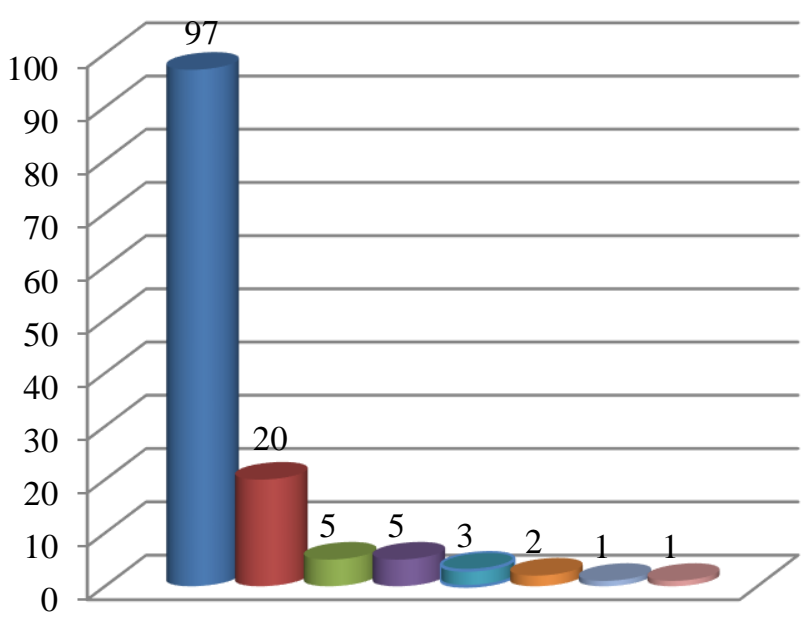

• Okul Öncesi Öğretmenler

• Okul Öncesi Öğretmen Adayları

• OÖ Öğretmenler ve Adaylar

• OÖ Öğretmenler ve ebeveynler

• OÖ Öğretmenler ve Okul öncesi dönem çocuklar

匹OÖ Öğretmenleri ve Yöneticiler

匹 OÖ Öğretmenler ve Okul Personeli

ఐÖ̈ Öğretmenliği Akademisyenleri

Şekil 4: Tezlerin Çalışma Grubuna Göre Dağılımı

Turkish Studies - Educational Sciences 


\section{Okul Öncesi Öğretmen Ve Öğretmen Adayları İle İlgili Yapılan Tezlerin Yürütüldü̆ğü Üniversitelere Göre Dağılımına İlişsin Bulgular}

İncelenen tezlerde okul öncesi öğretmen ve öğretmen adayları ile ilgili çalışmaların 21'inin (\% 15,4) Orta Doğu Teknik Üniversitesi’nde yapılarak ilk sırayı aldığı görülmektedir. Bu sırayı $16(\% 11,8)$ tez ile Gazi Üniversitesi takip etmektedir. Tezlerin hangi üniversitelerde yürütüldüğüne dair frekans ve yüzde bilgileri Tablo 2'de verilmiştir.

Tablo 2: Tezlerin Yürütüldüğü Üniversitelere Göre Dağılımı

\begin{tabular}{|c|c|c|c|c|c|c|}
\hline \multirow{2}{*}{ Üniversiteler } & \multicolumn{2}{|c|}{ Yüksek Lisans } & \multicolumn{2}{|c|}{ Doktora } & \multicolumn{2}{|c|}{ Toplam } \\
\hline & $\mathbf{f}$ & $\%$ & $\mathbf{f}$ & $\%$ & $\mathbf{f}$ & $\%$ \\
\hline Orta Doğu Teknik Üniversitesi & 14 & 11,6 & 7 & 43,7 & 21 & 15,4 \\
\hline Gazi Üniversitesi & 11 & 9,2 & 5 & 31,2 & 16 & 11,8 \\
\hline Çanakkale Onsekiz Mart Üniversitesi & 9 & 7,5 & $*$ & $*$ & 9 & 6,6 \\
\hline Abant İzzet Baysal Üniversitesi & 7 & 5,8 & $*$ & $*$ & 7 & 5,1 \\
\hline Yeditepe Üniversitesi & 6 & 5 & $*$ & $*$ & 6 & 4,4 \\
\hline Selçuk Üniversitesi & 4 & 3,3 & $*$ & $*$ & 4 & 2,9 \\
\hline Dokuz Eylül Üniversitesi & 4 & 3,3 & $*$ & $*$ & 4 & 2,9 \\
\hline Hacettepe Üniversitesi & 3 & 2,5 & 1 & 6,2 & 4 & 2,9 \\
\hline Erciyes Üniversitesi & 3 & 2,5 & $*$ & $*$ & 3 & 2,2 \\
\hline Pamukkale Üniversitesi & 3 & 2,5 & $*$ & $*$ & 3 & 2,2 \\
\hline Dumlupınar Üniversitesi & 3 & 2,5 & $*$ & $*$ & 3 & 2,2 \\
\hline Anadolu Üniversitesi & 3 & 2,5 & $*$ & $*$ & 3 & 2,2 \\
\hline Kahramanmaraş Sütçü İmam Üniversitesi & 3 & 2,5 & $*$ & $*$ & 3 & 2,2 \\
\hline Ankara Üniversitesi & 2 & 1,6 & 1 & 6,2 & 3 & 2,2 \\
\hline Karadeniz Teknik Üniversitesi & 2 & 1,6 & 1 & 6,2 & 3 & 2,2 \\
\hline Sakarya Üniversitesi & 3 & 2,5 & $*$ & $*$ & 3 & 2,2 \\
\hline Muğla Üniversitesi & 2 & 1,6 & $*$ & $*$ & 2 & 1,5 \\
\hline Atatürk Üniversitesi & 1 & 0,8 & 1 & 6,2 & 2 & 1,5 \\
\hline Adnan Menderes Üniversitesi & 2 & 1,6 & $*$ & $*$ & 2 & 1,5 \\
\hline Afyon Kocatepe Üniversitesi & 2 & 1,6 & $*$ & $*$ & 2 & 1,5 \\
\hline Çukurova Üniversitesi & 2 & 1,6 & $*$ & $*$ & 2 & 1,5 \\
\hline F1rat Üniversitesi & 2 & 1,6 & $*$ & $*$ & 2 & 1,5 \\
\hline Necmettin Erbakan Üniversitesi & 2 & 1,6 & $*$ & $*$ & 2 & 1,5 \\
\hline Yüzüncü Y1l Üniversitesi & 2 & 1,6 & $*$ & $*$ & 2 & 1,5 \\
\hline Marmara Üniversitesi & 2 & 1,6 & $*$ & $*$ & 2 & 1,5 \\
\hline Mehmet Akif Ersoy Üniversitesi & 2 & 1,6 & $*$ & $*$ & 2 & 1,5 \\
\hline Yakın Doğu Üniversitesi & 2 & 1,6 & $*$ & $*$ & 2 & 1,5 \\
\hline Diğer & 21 & 17,502 & $*$ & $*$ & 21 & 15,4 \\
\hline
\end{tabular}

Tablo 2'de "Diğer" olarak belirtilen üniversiteler frekans1 1 olarak belirlenen şu üniversiteleri kapsamaktadır:

- Ahi Evran Üniversitesi

- Aksaray Üniversitesi

- Atatürk Üniversitesi

- Bahçeşehir Üniversitesi

- Başkent Üniversitesi 
- Çağ Üniversitesi

- Dicle Üniversitesi

- Düzce Üniversitesi

- Fatih Üniversitesi

- İnönü Üniversitesi

- İstanbul Üniversitesi

- İstanbul Arel Üniversitesi

- İstanbul Aydın Üniversitesi

- Kafkas Üniversitesi

- Kastamonu Üniversitesi

- Maltepe Üniversitesi

- Mersin Üniversitesi

- Niğde Üniversitesi

- Okan Üniversitesi

- Recep Tayyip Erdoğan Üniversitesi

- Trakya Üniversitesi

6. Okul Öncesi Öğretmen Ve Öğretmen Adayları İle İlgili Yapılan Tezlerin Proje Desteği Alma Durumuna İliş̧kin Bulgular

Şekil 5'ten de anlaşılacağ 1 üzere, incelenen tezlerin 2'si (\% 1,5) proje desteği almış, 134'ü (\% 98,5) proje desteği almamıştır. Proje desteği alan tezlerden biri Dumlupınar Üniversitesi Bilimsel Araştırma Projesi, bir diğeri ise Türkiye Bilimsel ve Teknolojik Araştırma Kurumu (TÜBİTAK) 1001 Programı ve Anadolu Üniversitesi Bilimsel Araştırma Projeleri kapsamında destek almıştır.

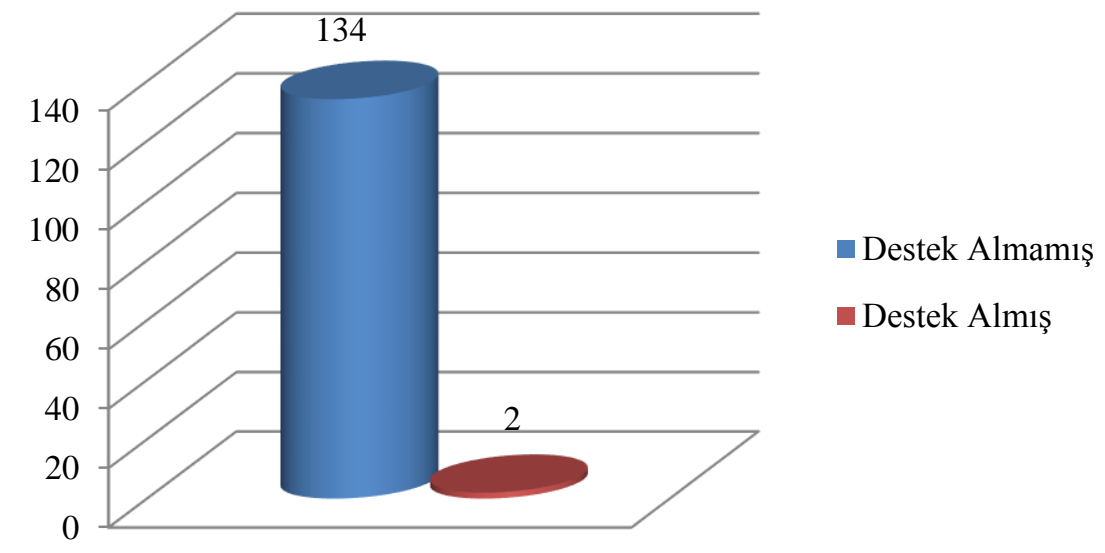

Şekil 5: Tezlerin Proje Desteği Alma Durumu

7. Okul Öncesi Öğretmen Ve Öğretmen Adayları İle İlgili Yapılan Tezlerin Araştırma Türlerine İlişkin Bulgular

Şekil 6'ten de anlaşılacağı üzere, tezlerin araştırma türleri incelendiğinde 92'si $(\%$ 67,6) nicel yöntem, 34’ü (\% 25) nitel yöntem, 10’u (\% 7,3) karma yöntem kullanılarak araştırılmıştır. 


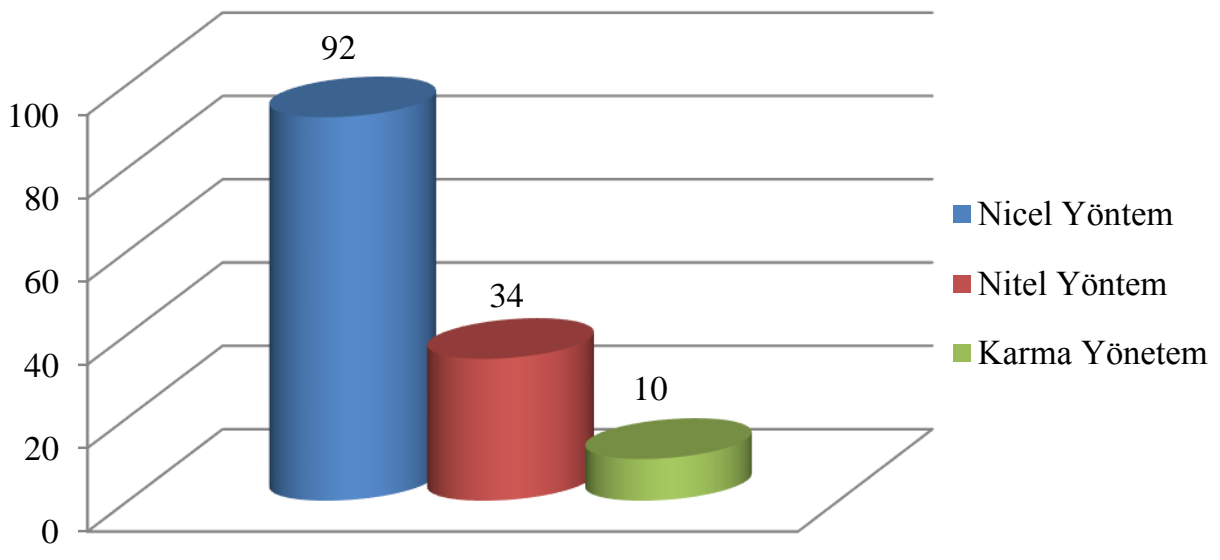

Şekil 6: Tezlerin Araştırma Türlerine Göre Dağılımı

\section{Okul Öncesi Öğretmen Ve Öğretmen Adayları İle İlgili Yapılan Tezlerin Çalışma Gruplarının Bölgelere Göre Dağılımına İlişkin Bulgular}

Şekil 7'dan da anlaşılacağı üzere, incelenen tezlerin çalışma grubundaki iller bölgelere göre düzenlendiğinde 53'ünün (\% 39) İç Anadolu Bölgesi'nde ve 9 farklı şehirde, 29'unun (\% 21,3) Marmara Bölgesi'nde ve 6 farklı şehirde, 24'ünün $(\% 17,6)$ Ege Bölgesi'nde ve 7 farklı şehirde, 12'sinin $(\% 8,8)$ Güneydoğu Anadolu Bölgesi'nde ve 3 farklı șehirde, 10'unun (\% 7,3) Karadeniz Bölgesi'nde ve 4 farklı şehirde, 9'unun (\% 6,6) Akdeniz Bölgesi'nde ve 5 farklı şehirde, 8'inin (\% 5,8) Doğu Anadolu Bölgesi'nde ve 4 farklı şehirde çalışıldığı görülmektedir.

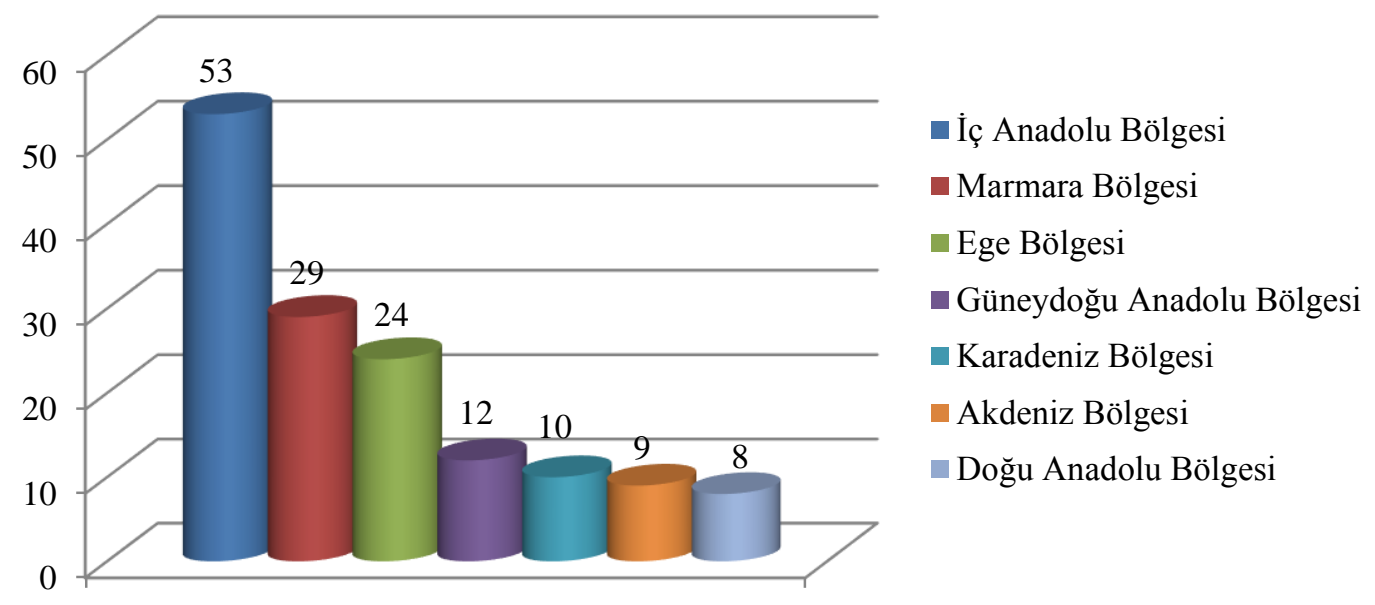

Şekil 7: Tezlerin Çalı̧̧ma Gruplarının Bölgelere Göre Dağılımı

\section{Okul Öncesi Öğretmen Ve Öğretmen Adayları İle İlgili Yapılan Tezlerin Çalışma Gruplarının Bulunduğu Şehirlere Göre Dağılımına İlişkin Bulgular}

Tezler çalışma gruplarının bulunduğu şehirlere göre incelendiğinde 32 (\% 23,5) çalışma ile Ankara'nın ilk sırada yer aldığı ve 1'er çalışma ile $(\% 0,7)$ Karaman, Burdur, Tekirdağ, Diyarbakır,

Turkish Studies - Educational Sciences

Volume 14 Issue 4, 2019 
Uşak, Niğde, Isparta, Elazı̆̆, Trabzon, Batman, Muş ve Aksaray’ın son sırada kaldığı görülmektedir. Bu bilgiye iliş̧kin frekans ve yüzde değerleri Tablo 3'te belirtilmiştir.

Tablo 3. Tezlerin Çalışma Gruplarının Bulunduğu Şehirlere Göre Dağılımı

\begin{tabular}{lcc}
\hline \multirow{2}{*}{ Şehirler } & \multicolumn{2}{c}{ Toplam } \\
\cline { 2 - 3 } & f & \% \\
\hline Ankara & 32 & 23,5 \\
\hline İstanbul & 12 & 8,8 \\
\hline Konya & 5 & 3,7 \\
\hline Çanakkale & 5 & 3,7 \\
\hline İzmir & 5 & 3,7 \\
\hline Bolu & 5 & 3,7 \\
\hline Sivas & 5 & 3,7 \\
\hline Eskişehir & 4 & 2,9 \\
\hline Muğla & 4 & 2,9 \\
\hline Afyon & 4 & 2,9 \\
\hline Denizli & 4 & 2,9 \\
\hline Sakarya & 4 & 2,9 \\
\hline Adıyaman, Gaziantep, Adana, Kütahya, Aydın, Kuzey Kıbrıs, Kayseri & 3 & 2,2 \\
\hline Kars, Edirne, Şanlıurfa, Kırklareli, Kastamonu, Mardin, Ağrı, Siirt, Balıkesir, & 2 & 1,5 \\
Antalya, Mersin & 2 & 0,7 \\
\hline $\begin{array}{l}\text { Karaman, Burdur, Tekirdağ, Diyarbakır, Uşak, Niğde, Isparta, Elazı̆̆, } \\
\text { Trabzon, Batman, Muş, Aksaray }\end{array}$ & 1 & \\
\hline
\end{tabular}

\section{Okul Öncesi Öğretmen Ve Öğretmen Adayları İle İlgili Yapılan Tezlerin Veri Toplama Araçlarına İlişkin Bulgular}

Şekil 8'den de anlaşılacağı üzere, tezler veri toplama araçlarına göre incelendiğinde 80'inde (\% $58,8)$ ölçek, 64'ünde (\% 47) form, 34'ünde (\% 25) görüşme, 27'sinde (\% 19,8) anket, 20'sinde (\% 14,7) envanter, 10 'unda $(\% 7,3)$ gözlem, 9'unda $(\% 6,6)$ test, 3'ünde (\% 2,2) odak grup tartışması ve 2 'sinde $(\%$ 1,5) mülakat kullanılmıştır.

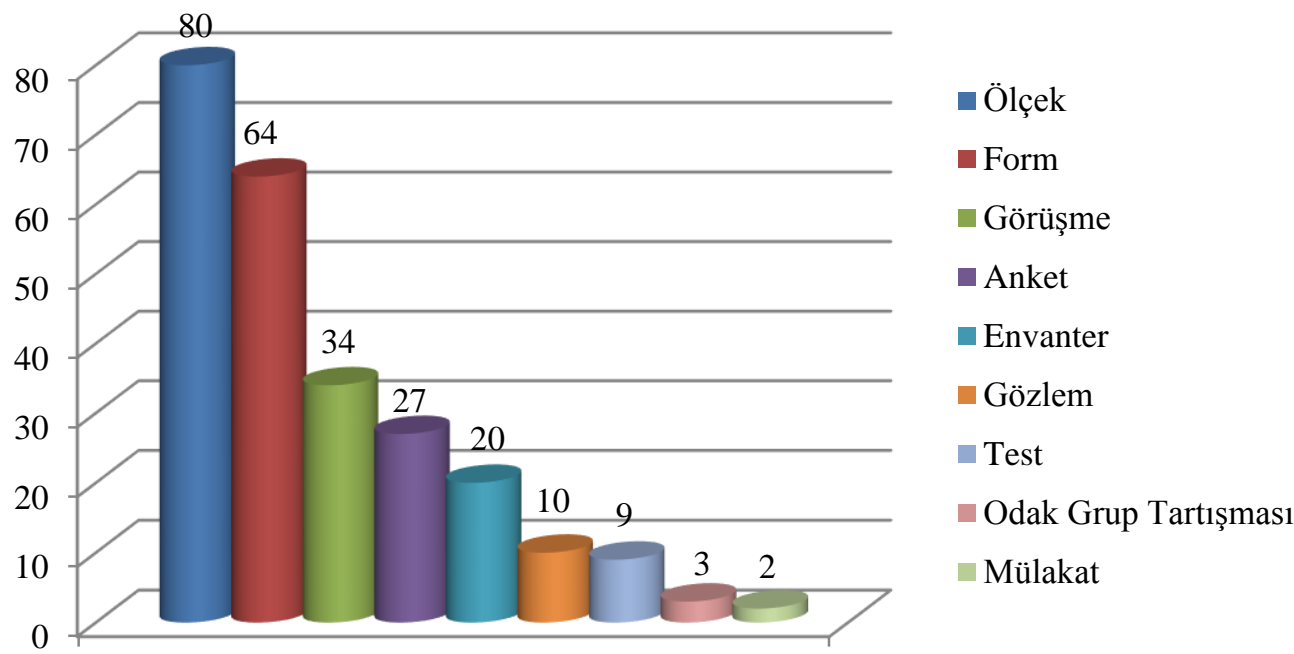

Şekil 8: Tezlerin Veri Toplama Araçlarına Göre Dağılımı

Turkish Studies - Educational Sciences

Volume 14 Issue 4, 2019 
11. Okul Öncesi Öğretmen Ve Öğretmen Adayları İle İlgili Yapılan Tezlerin Veri Analizinde Kullanılan İstatistiksel Yöntemlere İlişkin Bulgular

Tezlerin veri analizinde kullanılan istatistiksel yöntemler incelendiğinde $60(\% 44,1)$ frekans değeri ile ANOVA'nın (Tek Yönlü Varyans Analizi) ilk sırada yer aldığı görülmektedir. İkinci sırada ise $47(\% 37,5)$ frekans değeri ile t-testi yer almaktadır. Bu bilgiye ilişkin frekans ve yüzde değerleri Tablo 4'te belirtilmiştir.

Tablo 4: Tezlerin Veri Analizinde Kullanılan İstatistiksel Yöntemlere Göre Dağılımı

\begin{tabular}{|c|c|c|}
\hline \multirow{2}{*}{ İstatistiksel Yöntemler } & \multicolumn{2}{|c|}{ Toplam } \\
\hline & $\mathbf{f}$ & $\%$ \\
\hline ANOVA (Tek Yönlü Varyans Analizi) & 60 & 44,1 \\
\hline T-testi & 47 & 34,5 \\
\hline Kruskal Wallis-H testi & 33 & 24,3 \\
\hline Mann Whitney-U Testi & 33 & 24,3 \\
\hline İçerik Analizi & 28 & 20,6 \\
\hline $\begin{array}{l}\text { Tanımlayıcı İstatistiksel Metotlar (Frekans, Yüzde, Standart sapma, } \\
\text { Aritmetik ortalama...) }\end{array}$ & 23 & 16,9 \\
\hline Korelasyon Analizi & 18 & 13,2 \\
\hline Tukey testi & 12 & 8,8 \\
\hline Kolmogorov Smirnov Testi & 10 & 7,3 \\
\hline ki-kare testi & 10 & 7,3 \\
\hline Betimsel analiz & 7 & 5,1 \\
\hline LSD testi & 6 & 4,4 \\
\hline Faktör Analizi & 4 & 2,9 \\
\hline Scheffe Testi & 4 & 2,9 \\
\hline Wilcoxon S1ralı İsaretler testi & 4 & 2,9 \\
\hline Cronbach Alpha Yöntemi & 3 & 2,2 \\
\hline Frekans Analizi & 3 & 2,2 \\
\hline Diğer & 14 & 10,3 \\
\hline
\end{tabular}

Tablo 2'de "Diğer" olarak belirtilen ve frekansı 2 olarak belirlenen yöntemler şu şekildedir:

- Shapira Wilk Testi

- Kaiser-Mayer-Olkin (KMO) Testi

- Barlett's Testi

- Tamhane Testi

- Bonferroni Testi

- Post Hoc Analizi

Tablo 2'de "Diğer" olarak belirtilen ve frekansı 1 olarak belirlenen yöntemler şu şekildedir:

- MANOVA (Çok yönlü Varyans Analizi)

- Yarılama (split half) Yöntemi 


\section{İlişkin Bulgular \\ 12. Okul Öncesi Öğretmen Ve Öğretmen Adayları İle İlgili Yapılan Tezlerin Konusuna}

$\mathrm{Bu}$ çalışmanın konuları analiz edilirken de araştırmacının ve alanında uzman iki kişinin görüşleri alınarak içerik analizine başvurulmuştur. Temalar oluşturulurken Milli Eğitim Bakanlığı Öğretmen Yetiştirme ve Geliştirme Genel Müdürlüğü'nün yayınladığ Yeterliklerindeki boyut ve alt boyutlar da göz önünde bulundurulmuştur. Tezlerin konuları ile ilgili yapılan incelemede 55'inin (\% 40,4) tutum ve değerler alanında, 38'inin (\% 27,9) meslekî beceri alanında, 22'sinin (\% 16,1) meslekî bilgi alanında, 10’unun (\% 7,3) özel eğitim alanında, 10'unun $(\% 7,3)$ eğitim programları alanında ve 2 'sinin $(\% 1,4)$ ölçek çalışması alanında olduğu saptanmıştır. Bu bilgilere ilişkin frekans ve yüzde değerleri Tablo 5 'te belirtilmiştir.

Tablo 5: Tezlerin Konulara Göre Dağılımı

\begin{tabular}{lcccccc}
\hline \multirow{2}{*}{ Konu Temaları } & \multicolumn{2}{c}{ Yüksek Lisans } & \multicolumn{2}{c}{ Doktora } & \multicolumn{2}{c}{ Toplam } \\
\cline { 2 - 7 } & f & \% & f & \% & f & \% \\
\hline Tutum ve Değerler & 52 & 43,3 & 3 & 18,7 & 55 & 40,4 \\
\hline Meslekî Beceri & 28 & 23,3 & 10 & 62,5 & 38 & 27,9 \\
\hline Meslekî Bilgi & 21 & 17,5 & 1 & 6,2 & 22 & 16,1 \\
\hline Özel Eğitim & 10 & 8,3 & 0 & 0 & 10 & 7,3 \\
\hline Ĕğitim Programları & 8 & 6,6 & 2 & 12,5 & 10 & 7,3 \\
\hline Ölçek Çalışması & 2 & 1,7 & 0 & 0 & 2 & 1,4 \\
\hline
\end{tabular}

\section{Tartışma, Sonuç ve Öneriler}

Bu araştırmada, 2010-2018 yılları arasında okul öncesi öğretmen ve öğretmen adayları ile ilgili yüksek lisans ve doktora tezleri türüne, konusuna, araştırma türüne, yazıldığg dile, çalışma grubuna, yazıldığı yıla, yürütüldüğü üniversiteye, proje desteği alma durumuna, veri analizinde kullanılan istatistiksel yöntemlere, veri toplama araçlarına, çalışma grubundaki illere ve bölgelere göre incelenerek araştırma eğilimlerinin belirlenmesi amaçlanmıştır. Bu amaç doğrultusunda şu sonuçlara ulaşılmıştır:

İncelenen tezlerin büyük çoğunluğu yüksek lisans türünde yazılmıştır. Bu durumun sebebinin Türkiye'de okul öncesi öğretmenliği alanında yüksek lisans programına sahip üniversite sayısının doktora programına sahip üniversite sayısından daha fazla olmasından kaynaklandığı düşünülmektedir. Ayrıca bu konu ile ilgili yapılan tezlerin, yazarları tarafından YÖK tez veri tabanından tam metin olarak erişimine izin verilmemesinin ya da çeşitli nedenlerden dolayı güncel tezlerin veri tabanına eklenmemiş olmasının da yüksek lisans tez sayısının doktora tez sayısından oldukça fazla olması üzerinde etkili olabileceği düşünülebilir. Eğitim alanında yapılan tezlerin analiz edildiği çalışmalar incelendiğinde de yüksek lisans tezlerinin sayısının doktora tezlerinden oldukça fazla olduğu görülebilir (Aydın, Selvitopu ve Kaya, 2018; Bolat, 2016; Can Yaşar ve Aral, 2014; Gürdal, Bakioğlu ve Öztuna, 2005; Kardeş, Akman ve Yazıcı, 2018; Özenç ve Özenç, 2013; Özenç ve Özenç, 2018; Şahin, Göğebakan Yıldız ve Duman, 2011; Tatlı ve Adıüzel, 2012; Yaşar ve Papatğa, 2015)

2010-2018 yılları arasında yapılan yüksek lisans ve doktora tezlerinin y1llara göre dağılımının incelenmesi neticesinde tez sayılarının yıllara göre 12 ile 20 arasında değişiklik gösterdiği ancak yıllara göre artan ya da azalan homojen bir dağılım sergilenmediği söylenebilir. Her yıl üniversitelerde yeni yüksek lisans ve doktora programları açılmasına, bu durumla doğru orantılı şekilde yüksek lisans ve doktora yapan öğrenci sayılarının da artmasına rağmen yıllara göre dağılımda ilerleyen bir artışın olmamasının araştırma konusunun yalnızca okul öncesi öğretmen ve öğretmen adayları ile sınırlı tutulmasından kaynaklı olabileceği düşünülmektedir. Durukan, Atalay ve Şen'in (2015) yaptığ çalışmada Türkiye'de okul öncesi eğitimi alanında yapılan lisansüstü tezler incelenmiştir. Bu bağlamda son 14 yıl içerisinde yapılan 340 lisansüstü tez çeşitli açılardan gruplandırılmaya çalışılmıştır. 
Araştırmada elde edilen bulgular doğrultusunda okul öncesi alanında en fazla tezin 2010 yılında yayınlandığı görülmüştür.

İncelenen yüksek lisans ve doktora tezlerinin büyük bir çoğunluğu Türkçe dilinde yazılmıştır. Türkçe yazılan yüksek lisans tezleri, İngilizce yazılan yüksek lisans tezlerinden oldukça fazla iken, Türkçe ve İngilizce yazılan doktora tez sayıları birbirine oldukça yakındır. İngilizce yazılan tezlerin tamamının ise Orta Doğu Teknik Üniversitesi'nde yürütülen tez çalışmaları olduğu görülmektedir (Aras, 2012; Ata, 2015; Buldu, 2010; Buldu, 2016; Coşkun, 2015; Erden, 2010; Gülçiçek, 2017; Gülmez, 2012; İler, 2015; Karaduman, 2011; Özer, 2010; Özkanoğlu, 2015; Öztürk, 2010; Parlak Rakap, 2011; Sak, 2013; Sicim, 2011; Şahin 2013; Tekmen, 2012; Tezcan 2012; Y1lmaz, 2013; Y1lmaz, 2011).

2010-2018 yılları arasında yapılan yüksek lisans ve doktora tezlerinde okul öncesi öğretmenleriyle, okul öncesi öğretmen adaylarıyla, okul öncesi öğretmenleri ve öğretmen adaylarıyla, okul öncesi ögretmenleri ve ebeveynlerle, okul öncesi öğretmenleri ve okul öncesi dönem çocuklarıyla, okul öncesi öğretmenleri ve yöneticileriyle, okul öncesi öğretmenleri ve okul personeliyle ayrıca okul öncesi öğretmenliği bölümü akademisyenleri ile çalış1ldığı tespit edilmiştir. İncelenen tezlerin çoğunluğunun çalışma grubunu okul öncesi öğretmenlerinin oluşturduğu (Acar, 2016; Aktaş, 2013; Aras, 2012; Bağ, 2015; Bal, 2011; Bülbül, 2016; Ceylan, 2017; Coşkun, 2015; Daştan, 2016; Dereli, 2013; Erden, 2010; Erkuş, 2012; Fırat, 2016; Gezer, 2017; Göle, 2014; Gülkaya, 2016; Kadim, 2012; Kartaltepe, 2014; Orkunoğlu, 2016; Özkan, 2013; Öztürk, 2010; Sarran, 2017; Süngü, 2012; Şahin, 2013; Tepebağ, 2017; Türkdemir, 2013; Yıldırım, 2016; Y1lmaz, 2011; Zağl1, 2010; Zoroğlu, 2014), en az çalışmanın ise okul personeli ve okul öncesi öğretmenliği akademisyenleri ile yürütüldüğü belirlenmiştir. Genel olarak okul öncesi eğitime yönelik tüm paydaşların araştırmalara dâhil edildiği görülmektedir.

İncelenen tezlerde okul öncesi öğretmen ve öğretmen adayları ile ilgili yüksek lisans tezlerinin 48 farklı üniversitede, doktora tezlerinin ise 6 farklı üniversitede yürütüldüğü tespit edilmiştir. Yürütülen toplam 21 yüksek lisans ve doktora tez çalışması ile ilk sırayı Orta Doğu Teknik Üniversitesi'nin aldığ 1,16 yüksek lisans ve doktora tez çalışması ile de Gazi Üniversitesinin ikinci sırada yer aldığı görülmektedir. Yüksek lisans ve doktora tezlerinin belli üniversitelerde yoğun olarak yürütülmesinde, üniversitelerin ilgili bölümlerinde görev yapan öğretim üyelerinin yeterli sayı ve ünvanda olmalarının, ayrıca özellikle büyükşehirlerde bulunan bu üniversitelerde yürütülecek olan tez çalışmalarında örneklem gruplarına daha kolay ulaşılabiliyor olmasının da etkili olduğu düşünülmektedir. Araştırmanın bu bulgusunu destekleyen çalışmalar mevcuttur (Ahi ve Kıldan, 2013; Kardeş, Akman, ve Yazıcı, 2018).

İncelenen tezlerin genel olarak proje desteği almadığı; bir tezin üniversite Bilimsel Araştırma Projesi, başka bir tezin ise üniversite Bilimsel Araştırma Projesi (BAP) ve Türkiye Bilimsel ve Teknolojik Araştırma Kurumu (TÜBİTAK) 1001 Programı kapsamında desteklendiği belirlenmiştir. İncelenen 136 tez içerisinde yalnızca 2 tezin proje desteği almış olması, destek alan tez sayısının oldukça yetersiz olduğunu ortaya koymaktadır. Lisansüstü tezlerinin yürütülmesi sürecinde üniversitelerinden BAP ya da ulusal anlamda TÜBİTAK proje desteği almak araştırmacıları birçok mali yükten kurtararak, sunduğu çok sayıda fırsatla daha nitelikli çalışmalar yapabilmelerinin önünü açmaktadır. Araştırmacıların tez süreçlerinde proje desteği almamalarının; BAP ve TÜBİTAK proje süreçlerinin işleyişi hakkında yeterli bilgi sahibi olmamaları, tez danışmanları tarafından kendilerine gerekli bilgilendirmenin yapılmaması ve proje desteği için gerekli şartları taşımıyor olmalarından kaynaklandığ 1 düşünülmektedir.

2010-2018 y1lları arasında yapılan yüksek lisans ve doktora tezlerinin çoğunluğunda nicel araştırma yöntemleri kullanılırken, ikinci sırada nitel araştırma yöntemleri tercih edilmiştir. Tek bir çalışmanın ya da çalışmalar içerisindeki nitel ve nicel araştırma verilerinin toplamasını, analiz edilmesini ve yorumlanmasını içeren böylece daha derinlemesine bilgiye ulaşılmasını sağlayan karma 
yöntem ise çok az sayıda tercih edilmiştir. Nicel yöntemin, araştırma evreni düzeyinde genellenebilir nitelikte ölçülebilir ve güvenilir veriler üretmesi ve toplumda bir bütün olarak var olan yapı ve desenleri keşfetmeyi sağlaması nedeniyle daha çok tercih edildiği düşünülmektedir. Farklı disiplinlerde yapılan araştırmalar, tezlerde nicel desenli araştırmaların çoğunlukta olduğunu da ortaya koymaktadır. $\mathrm{Bu}$ eğilimin tek bir alana özgü olmayıp Türkiye'deki genel eğilimi yansıttı̆̆ı da söylenebilir. (Baba, Öksüz, Çevik ve Güven, 2011; Durukan, Atalay ve Şen,2015; Kardeş, Akman, ve Yazıc1, 2018; Ozan ve Köse, 2014; Öksüz, Barut ve Dicle, 2011; Özenç ve Özenç, 2018; Tarman, Acun ve Yüksel, 2010; Taştepe, Öztürk Serter, Yurdakul, Taygur Altıntaş ve Bütün Ayhan, 2016; Uysal, 2013; Yaşar ve Papatğa, 2015; Yeşilyurt, 2018; Yıldız, 2004).

İncelenen tezlerin çalışma grubundaki iller bölgelere göre düzenlendiğinde en fazla tez çalışmasının İç Anadolu Bölgesi'nde yürütüldüğü tespit edilmiştir. İç Anadolu Bölgesi'ni ikinci sırada Marmara Bölgesi, üçüncü sırada da Ege Bölgesi takip etmektedir. Bölgelerin sıralamasında belirleyici olan asıl noktanın şehirler olduğu düşünülmektedir. İç Anadolu Bölgesi'nde Ankara'nın; Marmara Bölgesi'nde İstanbul'un ve Ege Bölgesi'nde İzmir'in hem daha fazla çalışma grubuna ulaşabilme imkânıyla büyük şehir olmaları, hem köklü üniversitelerin bulunması hem de üniversite sayılarının diğer şehirlere nispeten fazla olması gibi sebeplerden ötürü daha fazla tez çalışmasının yürütülmesine olanak sağladığı düşünülmektedir. Yapılan çalışmalar da araştırmanın bu bulgusunu destekler niteliktedir (Ahi ve Kıldan, 2013; Yeşilyurt, 2018).

Tezler çalışma gruplarının bulunduğu şehirlere göre incelendiğinde, Ankara'nın ilk sırada yer aldığ 1 görülmektedir. Bu durumun sebebinin Tablo 2'de de gösterildiği üzere Orta Doğu Teknik Üniversitesi ve Gazi Üniversitesi'nde yürütülen tez çalışmaları olduğu söylenebilir. Ancak Karaman, Batman, Tekirdağ, Muş, Aksaray gibi yalnızca 1 tez çalışmasının yürütüldüğü şehirler de mevcuttur. Bu durumun nedeni de bu şehirlerdeki üniversitelerin okul öncesi eğitimi bölümündeki öğretim üyelerinin sayı olarak yetersizliği ve bu sebepten lisansüstü programlarına sınırlı sayıda öğrenci kabul edilmesi şeklinde açıklanabilir niteliktedir. Bu bulguyu destekler nitelikte çalışmalar mevcuttur (Ahi ve Kıldan, 2013; Kardeş, Akman ve Yazıc1, 2018).

İncelenen tezlerde veri toplama aracı olarak çoğunlukla ölçek kullanıldığı, en az mülakatın tercih edildiği belirlenmiştir. Tezlerin çoğunluğunda nicel araştırma yöntemlerinin kullanılması ve ölçeklerin kullanılabilirliğinin yüksek olması veri toplama aracı olarak ölçeklerin sıklıkla tercih edilmesini açıklamaktadır. Mülakatın en az tercih edilen veri toplama aracı olması ise nitel araştırma yöntemlerinin kullanıldığı tez sayısının az olmasından kaynaklandığı düşünülmektedir. Araştırmanın bu bulgusu eğitim alanında yapılan farklı çalışmaların bulgularıyla da örtüşmektedir (Alper ve Gülbahar, 2009; Erdem, 2011; Kaytez ve Durualp, 2014; Seçer, Ay, Ozan ve Yılmaz, 2014)

Tezlerin veri analiz yöntemleri incelendiğinde ilk sırada ANOVA (Tek Yönlü Varyans Analizi), ikinci sırada ise t- testinin yer aldığı görülmektedir. Tezlerde çoğunlukla nicel araştırma teknikleri tercih edildiği için parametrik testlerden ANOVA ve t-testi, nonparametrik testlerden ise Kruskall Wallis ve Mann Whitney-U testi yaygın olarak kullanılmaktadır. Nitel araştırma tekniklerinin tercih edildiği tezlerde ise içerik analizi kullanılmaktadır. Ahi ve Kıldan (2013) tarafından yapılan çalışma araştırmanın bu bulgusunu destekler niteliktedir.

İncelenen tezlerin konuları ele alındığında çoğunlukla öğretmenlerin tutum ve değerlerinin ele alındığı görülmektedir. Tutum ve değerler teması, Milli Eğitim Bakanlığı Öğretmen Yetiştirme Ve Geliştirme Müdürlügünün yayınladığı Öğretmenlik Mesleği Genel Yeterlilikleri arasında yer almaktadır ve milli, manevi ve evrensel değerler; öğrenciye yaklaşım; iletişim ve işbirliği; kişisel ve mesleki gelişim alt başlıklarını içermektedir. Bu alt başlıkların sınırları çerçevesinde, bir öğretmen milli manevi ve evrensel değerleri gözetmeyi; öğrencilerin gelişimini destekleyici tutum sergilemeyi; öğrenci, meslektaş, aile ve eğitimin diğer paydaşları ile etkili iletişim ve iş birliği kurmayı; öz değerlendirme yaparak kişisel ve mesleki gelişimine yönelik çalışmalara katılmayı hedefler. 
Araştırma sonuçlarına göre aşağıdaki önerilerde bulunulmuştur:

$\checkmark \quad$ Okul öncesi öğretmenleri ve öğretmen adayları ile ilgili karşılaştırmalı olarak yürütülen tez çalışmalarının arttırılmasının alana daha fazla katkı sağlayacağı düşünülmektedir.

$\checkmark \quad$ Okul öncesi eğitimi alanında İngilizce dilinde yürütülen tez çalışmalarının Orta Doğu Teknik Üniversitesi ile sınırlı kalmayarak diğer üniversitelerde de yaygınlaşması sağlanabilir.

$\checkmark \quad$ Yürütülecek tezlerin çalışma gruplarına erken çocukluk dönemindeki çocuklar, okul öncesi eğitim kurumlarındaki personeller ve okul öncesi öğretmenliği bölümü akademisyenleri de dahil edilebilir.

$\checkmark \quad$ Tez çalışmalarında daha derin bir bilgiye ulaşabilmek amacıyla nicel ve nitel yöntemlerin birlikte kullanıldığı karma yöntemin tercih edilmesi alana daha fazla katkı sağlayabilir.

$\checkmark \quad$ Yürütülen tezlerin daha fazla BAP ve TÜBİTAK desteği alabilmesi amacıyla araştırmacılar bu destekler konusunda detaylı bir şekilde bilgilendirilebilir.

$\checkmark \quad$ Ölçek geliştirilmesine yönelik yürütülen tez sayısı oldukça yetersiz olduğu için araştırmacıların bu konuda çalışmalar yapması desteklenebilir.

\section{KAYNAKÇA}

Acar, F. M. (2016). Okul öncesi ögrretmenlerinin tükenmişlik ve iş doyumu düzeylerinin bazı değişkenler açısından incelenmesi. Yayınlanmamış Yüksek Lisans Tezi. Çağ Üniversitesi, Sosyal Bilimler Enstitüsü, Mersin.

Açıkalın, A. (1998). Toplumsal kuramsal ve teknik yönleriyle okul yöneticiliği. Ankara: Pegem A Yayınc1lik.

Adıgüzel, İ. (2016). Okul öncesi öğretmenlerinin sınıf yönetimi becerileri ile tükenmişlik düzeyleri arasındaki iliş̧ki. Yayınlanmamış Yüksek Lisans Tezi. Recep Tayyip Erdoğan Üniversitesi, Sosyal Bilimler Enstitüsü, Rize.

Ahi, B. ve Kıldan, O. (2013). Türkiye'de okul öncesi eğitimi alanında yapılan lisansüstü tezlerin incelenmesi (2002-2011). Mehmet Akif Ersoy Üniversitesi Eğitim Fakültesi Dergisi, 13 (27), 23-46.

Aktaş, A. (2013). Okul öncesi öğretmenlerinin eğitim programındaki müzik etkinliklerini uygulama durumları: Niğde ili örneği. Yayınlanmamış Yüksek Lisans Tezi. Niğde Üniversitesi, Eğitim Bilimleri Enstitüsü, Niğde.

Aktemur Gürler, S (2017). Okul öncesi ögretmen adaylarının ögretmen yeterlilik alglları üzerine bir inceleme. Yayınlanmamış Yüksek Lisans Tezi. Başkent Üniversitesi, Eğitim Bilimleri Enstitüsü, Ankara.

Akyol Kılıç, M. (2014). Okul öncesi öğretmenlerinin yöneticilerinde algıladıkları liderlik stilleri ile kendi iş doyumu düzeyleri arasındaki ilişkinin incelenmesi (İstanbul-Manisa örneği). Yayınlanmamış Yüksek Lisans Tezi. Fatih Üniversitesi, Sosyal Bilimler Enstitüsü, İstanbul.

Alper, A. ve Gülbahar, Y. (2009). Trends and issues in educational technologies: A review of recent research in TOJET. The Turkish Online Journal of Educational Technology - TOJET, 8 (2), 124-135. 
Arabikoğlu, S. (2016). Okul öncesi öğretmenlerinin yöneticilerin liderlik uygulamalarını değerlendirmeleriyle örgüte güven ve okula bağlllık düzeylerinin incelenmesi. Yayınlanmamış Yüksek Lisans Tezi. Mehmet Akif Ersoy Üniversitesi, Eğitim Bilimleri Enstitüsü, Burdur.

Aral, N., Kandır, A. ve Can Yaşar, M. (2000). Okul öncesi eğitim 1. Ankara: Ya-Pa Yayın Pazarlama.

Aras, S. (2012). Okul öncesi ögrretmenlerinin sinlf yönetimi için öğretim düzenlenmesine yönelik algı ve uygulamalarının incelenmesi. Yayınlanmamış Yüksek Lisans Tezi. Orta Doğu Teknik Üniversitesi, Sosyal Bilimler Enstitüsü, Ankara.

Arı, M. (2003). Türkiye'de erken çocukluk eğitimi ve kalitenin önemi, M. Sevinç (Ed.). Erken çocuklukta gelişim ve eğitimde yeni yaklaşımlar içinde (ss. 31-35). İstanbul: Morpa Kültür Yayınları.

Arslan, Z. (2017). Okul Öncesi Öğretmenlerinin 2013 Okul Öncesi Eğitim Programını Uygulamada Karşılaştıkları Sorunların Düzeyi. Yayınlanmamış Yüksek Lisans Tezi. Kahramanmaraş Sütçü İmam Üniversitesi, Sosyal Bilimler Enstitüsü, Kahramanmaraş.

Arslantaş, H. (2016). Okul öncesi öğretmenlerinin empatik eğilim düzeyleri ile duygusal zekâ düzeyleri arasındaki ilişki. Yayınlanmamış Yüksek Lisans Tezi. Kahramanmaraş Sütçü İmam Üniversitesi, Sosyal Bilimler Enstitüsü, Kahramanmaraş.

Ata, A. (2015). Öğretmen-çocuk iletişim becerileri ve öz-yeterlik inançlarını etkileyen faktörler: okul öncesi ögretmenleri üzerine bir araştırma. Yayınlanmamış Yüksek Lisans Tezi. Orta Doğu Teknik Üniversitesi, Sosyal Bilimler Enstitüsü, Ankara.

Ata, S. (2010). Okul öncesi ögretmenlerinin bağlanma stilleri, duygusal zekâ düzeyleri ve empatik eğilimlerinin incelenmesi. Yayınlanmamış Yüksek Lisans Tezi. Muğla Üniversitesi, Sosyal Bilimler Enstitüsü, Muğla.

Ata, S. (2014). Okul öncesi ögrretmenlerde bağlanma ve sinıfyönetimi profillerinin anne bağlanmast ve çocuk yetiştirme tutumlarıyla ilişkilerinin incelenmesi. Yayınlanmamış Doktora Tezi. Hacettepe Üniversitesi, Eğitim Bilimleri Enstitüsü, Ankara.

Ateş, Ö. (2015). Okul öncesi ögretmen adaylarının aile katılım çalışmalarına yönelik öz yeterlik inançlarının incelenmesi. Yayınlanmamış Yüksek Lisans Tezi. Pamukkale Üniversitesi, Eğitim Bilimleri Enstitüsü, Denizli.

Aydemir, F. (2012). Okul öncesi ögretmenlerinin mesleki etik davranışlar hakkındaki görüşlerinin incelenmesi: Adlyaman ili örneği. Yayınlanmamış Yüksek Lisans Tezi. İnönü Üniversitesi, Eğitim Bilimleri Enstitüsü, Malatya.

Aydın, A. (2010). Okul öncesi öğretmenlerinin okul öncesi eğitim programına yönelik değerlendirmeleri. Yayınlanmamış Yüksek Lisans Tezi. Kafkas Üniversitesi, Sosyal Bilimler Enstitüsü, Kars.

Aydın, A., Selvitopu A. ve Kaya, M. (2018). Sınıf yönetimi alanındaki lisansüstü tezlerin incelenmesi. Abant İzzet Baysal Üniversitesi Eğitim Fakültesi Dergisi, 18 (1), 41-56.

Aydın, İ. (2013). Ĕgitim ve ögretimde etik (4. Baskı). Ankara: Pegem Akademi.

Ayekin, D. N. (2014). Anne-babaların ve okul öncesi öğretmenlerin cinsel istismara uğrayan çocuklara yönelik tutumlarının çeşitli değisşkenler açısından incelenmesi. Yayınlanmamış Yüksek Lisans Tezi. Gazi Üniversitesi, Eğitim Bilimleri Enstitüsü, Ankara. 
Azargün, Ö. (2017). Okul öncesi öğretmenlerinin mesleği tercih etme kararlılıklarının iş doyumlarına etkisi. Yayınlanmamış Yüksek Lisans Tezi. İstanbul Arel Üniversitesi, Sosyal Bilimler Enstitüsü, İstanbul.

Baba, M., Öksüz, Y., Çevik, C. ve Güven, E. (2011). 2005-2010 yılları arasında sınıf öğretmenliği alanında hazırlanan lisansüstü tezlerin incelenmesi. 10. Ulusal Sinıf Öğretmenliği Eğitimi Sempozyumu Bildiri Kitabı (692-695), Cumhuriyet Üniversitesi, Sivas.

Bağ, C. (2015). Okul öncesi ögrretmenlerinin öğretmen yeterlikleri ve hizmet içi eğitim ihtiyaçları. Yayınlanmamış Yüksek Lisans Tezi. Düzce Üniversitesi, Sosyal Bilimler Enstitüsü, Düzce.

Bahçeci Sansar, S. (2010). Okul öncesi ögretmenlerin fen ögrretimine yönelik tutumları ile fen etkinliklerinde kullandıklar yöntemler arasındaki ilişkinin incelenmesi (Kütahya ili örneği). Yayınlanmamış Yüksek Lisans Tezi. Abant İzzet Baysal Üniversitesi, Sosyal Bilimler Enstitüsü, Bolu.

Bal, M. (2011). Okul öncesi öğretmenlerinin problem çözme becerileri ile eleştirel düşünme eğilimleri arasındaki ilişkinin incelenmesi. Yayınlanmamış Yüksek Lisans Tezi. Abant İzzet Baysal Üniversitesi, Sosyal Bilimler Enstitüsü, Bolu.

Baş, A. (2016). Okul öncesi öğretmenlerinin örgütsel sosyalleşme ile tükenmişlik düzeyleri arasındaki ilişkinin incelenmesi. Yayınlanmamış Yüksek Lisans Tezi. Kahramanmaraş Sütçü İmam Üniversitesi, Sosyal Bilimler Enstitüsü, Kahramanmaraş.

Batman, N. (2015). Okul öncesi ögretmenlerinin örgütsel adalet algılarının iş tatmin düzeylerine etkisi. Yayınlanmamış Yüksek Lisans Tezi. Gazi Üniversitesi, Eğitim Bilimleri Enstitüsü, Ankara.

Bay, D. N. (2011). Okul öncesi öğretmenlerine verilen soru sorma becerisi öğretiminin etkisinin incelenmesi. Yayınlanmamış Doktora Tezi. Gazi Üniversitesi, Eğitim Bilimleri Enstitüsü, Ankara.

Bayrak, Ö. (2017). Okul öncesi ögretmenlerinin örgütsel bağlllıkları ve örgütsel vatandaşlık davranışları. Yayınlanmamış Yüksek Lisans Tezi. Sakarya Üniversitesi, Eğitim Bilimleri Enstitüsü, Sakarya.

Bayram, S. (2013). Okul öncesi ögretmenlerinin empatik düşünme becerileri ile öğrencileri motive etme düzeylerinin incelenmesi. Yayınlanmamış Yüksek Lisans Tezi. Erciyes Üniversitesi, Eğitim Bilimleri Enstitüsü, Kayseri.

Bolat, Y. (2016). Türkiye'de 2005-2015 yılları arasında mesleki ve teknik eğitim alanında yapılan lisansüstü tezlerin incelenmesi. Uluslararası Ĕ̈itim Bilimleri Dergisi, 3 (8), 151-167.

Buldu, M. (2010). Inandıklarını yapabiliyorlar mı? Okul öncesi ögretmenlerinin değerlendirmeye yönelik görüş ve uygulamalarının incelenmesi. Yayınlanmamış Yüksek Lisans Tezi. Orta Doğu Teknik Üniversitesi, Sosyal Bilimler Enstitüsü, Ankara.

Buldu, M. (2016). Okul öncesi ögrretmen adaylarının mesleki yatkınlık gelişsimleri ve uygulamaları. Yayınlanmamış Doktora Tezi. Orta Doğu Teknik Üniversitesi, Sosyal Bilimler Enstitüsü, Ankara.

Buldur, A. (2014). Okul öncesi ögretmen adaylarının fen eğitimine yönelik öz yeterlikleri başarı amaç oryantasyonları ve ögrenme yaklaşımları arasındaki ilişskinin incelenmesi. Yayınlanmamış Yüksek Lisans Tezi. Gazi Üniversitesi, Eğitim Bilimleri Enstitüsü, Ankara.

Bulut, M. (2015). Okul öncesi ögrretmen ve ögretmen adaylarında çok kültürlü kişiliğin çok kültürlü eğitim tutumları üzerindeki etkisinin incelenmesi. Yayınlanmamış Yüksek Lisans Tezi. Dumlupınar Üniversitesi, Eğitim Bilimleri Enstitüsü, Kütahya. 
Bülbül, N. (2016). Okul öncesi öğretmenlerinin matematik eğitimine ilişkin inançları ve öz yeterlik düzeylerinin bazı değişkenlere göre incelenmesi. Yayınlanmamış Yüksek Lisans Tezi. Gazi Üniversitesi, Eğitim Bilimleri Enstitüsü, Ankara.

Can Yaşar, M. ve Aral, N. (2014). Türkiye'de okul öncesinde drama alanında yapılan lisansüstü tezlerin incelenmesi. Mehmet Akif Ersoy Üniversitesi Eğitim Fakültesi Dergisi, 11 (22), 70-90.

Ceylan, E. A. (2017). Okul öncesi ögretmenlerinin çocuk sevme düzeyleri ile iletişsim becerileri arasındaki ilişskinin incelenmesi. Yayınlanmamış Yüksek Lisans Tezi. Aksaray Üniversitesi, Sosyal Bilimler Enstitüsü, Aksaray.

Coşkun, T. (2015). Okul öncesi öğretmenlerinin çocukların katılım haklarına ilişkin inançları. Yayınlanmamış Yüksek Lisans Tezi. Orta Doğu Teknik Üniversitesi, Sosyal Bilimler Enstitüsü, Ankara.

Çakır, N. (2010). Okul öncesi öğretmenlerinin disiplin anlayışları ile iç-dış denetim odakları arasındaki ilişki: Çanakkale ili örneği. Yayınlanmamış Yüksek Lisans Tezi. Çanakkale Onsekiz Mart Üniversitesi, Sosyal Bilimler Enstitüsü, Çanakkale.

Çakmaz, B. (2010). Okul öncesi öğretmenlerinin eğitim teknolojilerini kullanma durumlarının incelenmesi. Yayınlanmamış Yüksek Lisans Tezi. Abant İzzet Baysal Üniversitesi, Sosyal Bilimler Enstitüsü, Bolu.

Çalhan, R. (2012). Iş̧ birliğine dayalı ögrenme yönteminin okul öncesi öğretmen adaylarının konuşma becerileri üzerine etkisi. Yayınlanmamıș Doktora Tezi. Atatürk Üniversitesi, Eğitim Bilimleri Enstitüsü, Erzurum.

Çek, F. (2011). Bağımsız anaokulu ve ilköğretim okulu müdürlerinin kültürel liderlik davranışları ile okul öncesi ögretmenlerinin iş doyumu arasındaki ilişsi. Yayınlanmamış Yüksek Lisans Tezi. Dokuz Eylül Üniversitesi, Eğitim Bilimleri Enstitüsü, İzmir.

Daştan, Ş. (2016). Okul öncesi ögrretmenlerinin öz-yeterlik düzeyleri ile üstün yeteneklilerin eğitimine yönelik tutumlarının karşılaştırılması. Yayınlanmamış Yüksek Lisans Tezi. Gazi Üniversitesi, Eğitim Bilimleri Enstitüsü, Ankara.

Demirdöğen, N. (2013). Okul öncesi ögretmenlerinin tükenmişlik düzeyleri ile psikolojik yardım arayışları arasındaki ilişkinin incelenmesi. Yayınlanmamış Yüksek Lisans Tezi. Yeditepe Üniversitesi, Sosyal Bilimler Enstitüsü, İstanbul.

Dereli, H. M. (2013). Reggio Emilia temelli dokümantasyon eğitiminin okul öncesi öğretmenlerinin demokratik tutum ve çocuk-merkezli uygulamaları üzerindeki etkisi. Yayınlanmamış Yüksek Lisans Tezi. Hacettepe Üniversitesi, Eğitim Bilimleri Enstitüsü, Ankara.

Dewey, J. (2008). Okul ve toplum. (Çev: H.A. Başman). Ankara: Pegem Akademi Yayınevi.

Doğan Demircioğlu, Z. (2014). Sinıf ve okul öncesi ögretmenlerinin yazmayı etkileyen faktörlere iliskin görüşlerinin incelenmesi. Yayınlanmamış Yüksek Lisans Tezi. Dumlupınar Üniversitesi, Eğitim Bilimleri Enstitüsü, Kütahya.

Doğan, İ. (2014). Okul öncesi öğretmen adaylarının bilimsel süreç becerilerinin belirlenmesi. Yayınlanmamış Yüksek Lisans Tezi. Dumlupınar Üniversitesi, Eğitim Bilimleri Enstitüsü, Kütahya.

Duran, K. (2014). Okul öncesi öğretmenlerinin mesleki etik davranışları algılama düzeylerinin ve etik ikilemleri çözümlemelerinin incelenmesi. Yayınlanmamış Yüksek Lisans Tezi. Hacettepe Üniversitesi, Eğitim Bilimleri Enstitüsü, Ankara. 
Durukan, H., Atalay, Y. ve Şen, S. N. (2015). Türkiye'de 2000- 2014 yılları arasında okul öncesi eğitimi alanında yapılan yüksek lisans tezlerinin incelenmesi. Dicle Üniversitesi Ziya Gökalp Eğitim Fakültesi Dergisi, 26, 62-77.

Düzgün, Ü. (2014). Okul öncesi öğretmenlerinin okul öncesi eğitim programı ve 2012 değişikliklerinin uygulanmasına ilişskin görüşleri (Kayseri ili örneği). Yayınlanmamış Yüksek Lisans Tezi. Erciyes Üniversitesi, Eğitim Bilimleri Enstitüsü, Kayseri.

Erdem, D. (2011). Türkiye'de 2005-2006 yılları arasında yayımlanan eğitim bilimleri dergilerindeki makalelerin bazı özellikler açısından incelenmesi: Betimsel bir analiz. Eğitimde ve Psikolojide Ölçme ve Değerlendirme Dergisi, 2 (1), 140-147.

Erden, E. (2010). Okul öncesi öğretmenlerinin ĕ̆itim programını uygulama sırasında yaşadı̆̆ sorunlar. Yayınlanmamış Yüksek Lisans Tezi. Orta Doğu Teknik Üniversitesi, Sosyal Bilimler Enstitüsü, Ankara.

Ergel, A. (2014). Okul öncesi öğretmenlerinin maruz kaldıkları psikolojik şiddetin tükenmişlik düzeylerine etkisi. Yayınlanmamış Yüksek Lisans Tezi. Fırat Üniversitesi, Eğitim Bilimleri Enstitüsü, Elazığ.

Ergen, Ü. (2014). Temel eğitim kurumları yöneticilerinin yönetsel süreç becerilerine ilişkin okul öncesi ögretmenlerinin görüşleri. Yayınlanmamış Yüksek Lisans Tezi. Okan Üniversitesi, Sosyal Bilimler Enstitüsü, İstanbul.

Erkuş, S. (2012). Okul öncesi öğretmenlerinin okul öncesi eğitim programındaki değerler ĕgitimine ilişkin görüşlerinin değerlendirilmesi. Yayınlanmamış Yüksek Lisans Tezi. Dicle Üniversitesi, Eğitim Bilimleri Enstitüsü, Diyarbakır.

Ertürk, M. (2012). Özel ve devlet okullarında çalışan okul öncesi öğretmenlerin demografik değişkenlere bağlı olarak mesleki tükenmişlik ve anksiyete düzeylerinin karşılaştırılması. Yayınlanmamış Yüksek Lisans Tezi. Maltepe Üniversitesi, Sosyal Bilimler Enstitüsü, İstanbul.

Eser Kabakçıŏlu, Ş. (2010). Okul öncesi ögretmenlerinde iş doyumu, meslektaş ilişkileri ve okul idaresi desteği arasindaki ilişkilerin incelenmesi: Tekirdă̆ ili örneği. Yayınlanmamış Yüksek Lisans Tezi. Çanakkale Onsekiz Mart Üniversitesi, Sosyal Bilimler Enstitüsü, Çanakkale.

Fırat, Z. S. (2016). Okul öncesi ögretmenlerinin doğal matematik dilini kullanımlarına ilişskin görüşleri ile uygulamalarının karşılaştırılması. Yayınlanmamış Yüksek Lisans Tezi. Ankara Üniversitesi, Eğitim Bilimleri Enstitüsü, Ankara.

Gencer, H. (2013). Denizli ili merkezinde çalışan okul öncesi öğretmenlerinin yabancı cisme bağlı hava yolu tıkanıkliğı konusundaki bilgi durumu. Yayınlanmamış Yüksek Lisans Tezi. Pamukkale Üniversitesi, Sağlık Bilimleri Enstitüsü, Denizli.

Gezer, M. S. (2017). Sinıfinda kaynaştırma öğrencisi bulunan okul öncesi öğretmenlerinin kaynaştırma eğitimine yönelik rol algılarının belirlenmesi. Yayınlanmamış Yüksek Lisans Tezi. Anadolu Üniversitesi, Eğitim Bilimleri Enstitüsü, Eskişehir.

Gök, A. (2010). Okul öncesi ögretmenlerinin bilişim teknolojileri kullanma durumları ve bunun öğrenci ilgi ve dikkat düzeyine ilişkin görüşler. Yayınlanmamış Yüksek Lisans Tezi. Yeditepe Üniversitesi, Sosyal Bilimler Enstitüsü, İstanbul.

Gölbaşı, E. (2013). Okul öncesi öğretmenlerinin müzik etkinliklerindeki mesleki yeterliliğinin değerlendirilmesi. Yayınlanmamış Yüksek Lisans Tezi. Marmara Üniversitesi, Eğitim Bilimleri Enstitüsü, İstanbul. 
Göle, M. O. (2014). Okul öncesi öğretmenlerin nitelikli bir okul öncesi eğitim programında bulunması gereken özelliklere ilişkin görüşlerinin incelenmesi. Yayınlanmamış Yüksek Lisans Tezi. Gazi Üniversitesi, Eğitim Bilimleri Enstitüsü, Ankara.

Görgün, B. (2013). Sinıfinda özel gereksinimli ögrenci olan okul öncesi öğretmenlerinin ögretmen yardımcısının rol ve sorumlulukları hakkındaki görüşleri. Yayınlanmamış Yüksek Lisans Tezi. Anadolu Üniversitesi, Eğitim Bilimleri Enstitüsü, Eskişehir.

Gülçiçek, T. (2017). Ebeveynlerin erkek okul öncesi öğretmenleri ile ilgili algllarının incelenmesi. Yayınlanmamış Yüksek Lisans Tezi. Orta Doğu Teknik Üniversitesi, Sosyal Bilimler Enstitüsü, Ankara.

Gülkaya, Ş. (2016). Okul öncesi ögretmenlerinin, üstün yetenekli çocuklar hakkındaki algl, görüş ve eğitim ihtiyaçlarının belirlenmesi. Yayınlanmamış Yüksek Lisans Tezi. Yakın Doğu Üniversitesi, Yurtdış1 Enstitü, KKTC.

Gülmez Dağ, G. (2012). Okul öncesi ögretmen eğitimi programlarının etkililĭgi: Okul öncesi ögretmenlerinin algıları. Yayınlanmamış Yüksek Lisans Tezi. Orta Doğu Teknik Üniversitesi, Sosyal Bilimler Enstitüsü, Ankara.

Gün, P. (2012). Okul öncesi öğretmenlerinin duygusal zekâ yeterlikleri ile ögretimsel liderlik davranışları arasındaki ilişkinin incelenmesi: Gaziantep ili örneği. Yayınlanmamış Yüksek Lisans Tezi. Gaziantep Üniversitesi, Sosyal Bilimler Enstitüsü, Gaziantep.

Güney, F. (2012). Okul öncesi ögretmenlerinin zihinsel yetersizliği bulunan öğrencilerin erken okuryazarlık becerilerinin desteklenmesine ilişkin görüşleri. Yayınlanmamış Yüksek Lisans Tezi. Abant İzzet Baysal Üniversitesi, Eğitim Bilimleri Enstitüsü, Bolu.

Güney, M. Y. (2016). Yapılandırmacı yaklaşıma uygun olarak geliştirilen etkinliklerin okul öncesi ögretmen adaylarının tutum ve başarısına etkisi. Yayınlanmamış Yüksek Lisans Tezi. Kastamonu Üniversitesi, Fen Bilimleri Enstitüsü, Kastamonu.

Gürdal, A., Bakioğlu, A. ve Öztuna, A. (2005). Fen bilgisi eğitimi lisansüstü tezlerinin incelenmesi. Buca Eğitim Fakültesi Dergisi, 17, 53-58

Gürkan, T. (2005). Öğretmen nitelikleri, görev ve sorumlulukları. A. Oktay, Ö. P. Unutkan (Ed.). Okul öncesi eğitimde güncel konular içinde (61-84). İstanbul: MorpaYayınları.

Güven, G. (2011). Farkl eğitim modelleri kullanılarak uygulanan aile eğitim ve aile katılım programlarının okul öncesi ögretmenlerinin uygulamalarına ve ebeveynlerin görüşlerine etkisinin incelenmesi. Yayınlanmamış Doktora Tezi. Gazi Üniversitesi, Eğitim Bilimleri Enstitüsü, Ankara.

Hacısalihoğlu Karadeniz, M. (2011). Okul öncesi ögretmenlerinin sınıf içi matematik uygulamalarının okul öncesi eğitim programına uyumluluğu. Yayınlanmamış Doktora Tezi. Karadeniz Teknik Üniversitesi, Eğitim Bilimleri Enstitüsü, Trabzon.

Haseski Demir, F. (2015). Okulöncesi ĕgitim kurumlarında fen eğitiminde kullanılan materyallerin okul öncesi ögretmenlerinin görüşlerine dayalı olarak değerlendirilmesi. Yayınlanmamış Yüksek Lisans Tezi. Çanakkale Onsekiz Mart Üniversitesi, Eğitim Bilimleri Enstitüsü, Çanakkale.

İler, C. (2015). Okul öncesi ögrretmen adaylarının kaynaştırma eğitimi hakkındaki inançlarının kişilik özelliklerine iliş̧kin olarak incelenmesi. Yayınlanmamış Yüksek Lisans Tezi. Orta Doğu Teknik Üniversitesi, Sosyal Bilimler Enstitüsü, Ankara. 
İlkay, N. (2017). Okul öncesi ögrretmen adaylarının teknolojik pedagojik alan bilgilerine yönelik öz yeterlikleri (Sakarya Üniversitesi örneği). Yayınlanmamış Yüksek Lisans Tezi. Sakarya Üniversitesi, Eğitim Bilimleri Enstitüsü, Sakarya.

İşcen Karasu, F. (2017). Performans geribildiriminin okul öncesi ögretmenlerinin önleyici sinıfyönetimi stratejileri ile özel gereksinimli çocuk çıktıları üzerindeki etkisi. Yayınlanmamış Doktora Tezi. Ankara Üniversitesi, Eğitim Bilimleri Enstitüsü, Ankara.

Kadim, M. (2012). Okul öncesi öğretmenlerinin oyun öğretimine ilişkin öz-yeterliklerinin incelenmesi. Yayınlanmamış Yüksek Lisans Tezi. Abant İzzet Baysal Üniversitesi, Eğitim Bilimleri Enstitüsü, Bolu.

Kanak, M. (2015). Okul öncesi ögretmen adaylarının duygusal ihmal ve istismara yönelik bilgi ve farkındalıklarına destek eğitim programının etkisi. Yayınlanmamış Doktora Tezi. Gazi Üniversitesi, Eğitim Bilimleri Enstitüsü, Ankara.

Kaptan, S. (1998). Bilimsel araştırma ve istatistik teknikleri (11. Bask1). Ankara: Tek Işık Web Ofset.

Karaduman, M. A. (2011). Okul öncesi öğretmen adaylarının mesleklerine ilişkin tutumlarında cinsiyetin ve cinsiyet rolünün etkisinin incelenmesi. Yayınlanmamış Yüksek Lisans Tezi. Orta Doğu Teknik Üniversitesi, Sosyal Bilimler Enstitüsü, Ankara.

Karakaş, T. (2016). Okul öncesi öğretmen adaylarının bilimsel yaratıcıllkları. Yayınlanmamış Yüksek Lisans Tezi. Ahi Evran Üniversitesi, Fen Bilimleri Enstitüsü, Kırşehir.

Kardeş, S., Akman, B. ve Yazıcı, D. N. (2018). Üstün yetenekliler alanında yapılmış tezlerin analizi. Kuramsal Ĕgitimbilim Dergisi, 11 (3), 411-430.

Kartaltepe, O. (2014). Okul öncesi öğretmenlerinin barlş eğitimine yönelik görüşlerinin incelenmesi. Yayınlanmamış Yüksek Lisans Tezi. Hacettepe Üniversitesi, Eğitim Bilimleri Enstitüsü, Ankara.

Kaytez, N. ve Durualp, E. (2014). Türkiye'de okul öncesinde oyun ile ilgili yapılan lisansüstü tezlerin incelenmesi. Uluslararası Türk Eğitim Bilimleri Dergisi, 2 (2), 110-122.

Kefeli, H. (2016). Okul öncesi öğretmenlerinin çocuk istismarı ve ihmali davranışları ile kurum personelinin konuya ilişkin görüşleri. Yayınlanmamış Yüksek Lisans Tezi. Ankara Üniversitesi, Eğitim Bilimleri Enstitüsü, Ankara.

Keleş, O. (2013). Okul öncesi öğretmen adaylarının ve okul öncesi öğretmenlerinin sinıf yönetimine ilişkin tutum ve inançlarının incelenmesi. Yayınlanmamış Yüksek Lisans Tezi. Çukurova Üniversitesi, Sosyal Bilimler Enstitüsü, Adana.

Kıhrı, G. (2013). Okul öncesi öğretmenleri mesleğe yabancılaşma ölçeğinin geliştirilmesi ve bir örnek uygulama. Yayınlanmamış Yüksek Lisans Tezi. Yeditepe Üniversitesi, Sosyal Bilimler Enstitüsü, İstanbul.

Koç, F. (2015). Okul öncesi öğretmenlerinin okul öncesi eğitim programındaki etkinliklere yönelik öz yeterlik inançlarının incelenmesi. Yayınlanmamış Yüksek Lisans Tezi. Yüzüncü Yı1 Üniversitesi, Eğitim Bilimleri Enstitüsü, Van.

Koran, N. (2017). Sinıflarda katılım hakkı: Okul öncesi ögretmenlerinin çocuk katılımını desteklemeye yönelik anlayışları ve geliştirilmesi. Yayınlanmamış Doktora Tezi. Gazi Üniversitesi, Eğitim Bilimleri Enstitüsü, Ankara. 
Koyuncu Şahin, M. (2015). Okul öncesi ögretmenlerinin öz güvenleri ve mesleki tutumlarının incelenmesi. Yayınlanmamış Yüksek Lisans Tezi. Afyon Kocatepe Üniversitesi, Sosyal Bilimler Enstitüsü, Afyon.

Koyutürk, N. (2014). Sinıfinda kaynaştırma öğrencisi olan ve olmayan okul öncesi öğretmenlerinin iş doyumu ve tükenmişlik düzeylerinin belirlenmesi. Yayınlanmamış Yüksek Lisans Tezi. Mehmet Akif Ersoy Üniversitesi, Eğitim Bilimleri Enstitüsü, Burdur.

Köroğlu, A. Y. (2014). Okul öncesi öğretmenlerinin ve ögretmen adaylarının bilişim teknolojileri öz yeterlik algıları, teknolojik araç gereç kullanım tutumları ve bireysel yenilikçilik düzeylerinin incelenmesi. Yayınlanmamış Yüksek Lisans Tezi. Gazi Üniversitesi, Eğitim Bilimleri Enstitüsü, Ankara.

Kunt Bulut, M. (2015). Okul öncesi ögretmenlerinin çocukluk anlayışı. Yayınlanmamış Yüksek Lisans Tezi. Gazi Üniversitesi, Eğitim Bilimleri Enstitüsü, Ankara.

Kuyucak, E. (2013). Okul öncesi ögrretmenlerinin okul yöneticilerinden beklentileri ve karşılanma düzeyleri. Yayınlanmamış Yüksek Lisans Tezi. Yeditepe Üniversitesi, Sosyal Bilimler Enstitüsü, İstanbul.

Milli Eğitim Bakanlığı (MEB), (1973). Milli eğitim temel kanunu, 14/6/1973 tarih ve 1739 kanun numaras1, http://www.mevzuat.gov.tr/MevzuatMetin/1.5.1739.pdf Erişim tarihi: 10.02.2018.

MEB, (1993). 14. Milli eğitim şûrası (27-29 Eylül 1993). http://ttkb.meb.gov.tr/meb_iys_dosyalar/2014_10/02113548_14_sura.pdf Erişim tarihi: 12.01.2018.

MEB Okul Öncesi Eğitimi Genel Müdürlüğü, (2006). 36-72 aylık çocuklar için okul öncesi eğitim programı. Ankara: Devlet Kitapları Müdürlüğü.

MEB, (2013). Okul öncesi ĕgitim programi. Ankara. http://tegm.meb.gov.tr/dosya/okuloncesi/ooproram.pdf Erişim tarihi: 10.02.2018.

MEB, (2017a). Öğretmen strateji belgesi 2017-2023. Ankara: Öğretmen Yetiştirme ve Eğitimi Genel Müdürlüğü.

MEB, (2017b). Öğretmenlik meslĕgi genel yeterlilikleri belgesi. Ankara: Öğretmen Yetiştirme ve Eğitimi Genel Müdürlüğü.

Merç, A. (2011). Sosyal bilgiler ve okul öncesi ögretmenliğinde eğitim gören öğrencilerin mekân bilişi ve harita okuma becerisi. Yayınlanmamış Yüksek Lisans Tezi. Adnan Menderes Üniversitesi, Sosyal Bilimler Enstitüsü, Aydın.

Mutlu, E. (2010). Erken çocukluk dönemindeki çocukların (60-72 ay) düşünme düzeylerinin ve okul öncesi ögrretmenlerinin düşünme eğitimi ile ilgili tutumlarının incelenmesi. Yayınlanmamış Yüksek Lisans Tezi. Çanakkale Onsekiz Mart Üniversitesi, Sosyal Bilimler Enstitüsü, Çanakkale.

Mutlu, N. (2016). Okul öncesi ögretmenlerinin mesleki yeterlilik algılarının belirlenmesi. Yayınlanmamış Yüksek Lisans Tezi. Yakın Doğu Üniversitesi, Yurtdışı Enstitü, KKTC.

Orkunoğlu, Y. M. (2016). Okul öncesi öğretmenlerinin fen öğretimine yönelik tutumlarl ile öz yeterlilik düzeyleri arasındaki ilişsinin incelenmesi (İstanbul ili Ataşehir ilçesi örneği). Yayınlanmamış Yüksek Lisans Tezi. Yeditepe Üniversitesi, Eğitim Bilimleri Enstitüsü, İstanbul.

Ozan, C. ve Köse, E. (2014). Eğitim programları ve öğretim alanındaki araştırma eğilimleri, Sakarya University Journal of Education, 4 (1), 116-136. 
Öksüz, Y., Barut, Y. ve Dicle, A. N. (2011). Eğitim bilimleri enstitüsünde yapılan tezlerin çeşitli yönleriyle incelenmesi. Samsun Sempozyumu: Samsun'a Bir Parantez Açıyoruz, (13-16 Ekim 2011), Samsun.

Öncü, B. (2017). Okul öncesi yöneticilerinin algilanan liderlik stilleri ile okul öncesi öğretmenlerinin yaşadıkları örgütsel sessizlik arasındaki ilişkinin incelenmesi (Kırklareli ili örneği). Yayınlanmamış Yüksek Lisans Tezi. Bahçeşehir Üniversitesi, Eğitim Bilimleri Enstitüsü, İstanbul.

Özdemir, C. C. (2013). Okul öncesi öğretmenliği 3. sınıf öğrencilerine verilen Reggio Emilia yaklaşımı konulu eğitim programının etkililiğinin incelenmesi. Yayınlanmamış Yüksek Lisans Tezi. Abant İzzet Baysal Üniversitesi, Eğitim Bilimleri Enstitüsü, Bolu.

Özdemir, H. (2010). Okul öncesi ögretmenlerinin kaynaştırma uygulamasına ilişskin görüşlerinin incelenmesi. Yayınlanmamış Yüksek Lisans Tezi. Trakya Üniversitesi, Sosyal Bilimler Enstitüsü, Edirne.

Özenç, M. ve Özenç, E. G. (2013). Türkiye'de üstün yetenekli öğrencilerle ilgili yapılan lisansüstü eğitim tezlerinin çok boyutlu olarak incelenmesi. Türkiye Sosyal Araştırmalar Dergisi, 171, 1328.

Özenç, E. G. ve Özenç, M. (2018). Sınıf öğretmenliği bilim dalında yapılan lisansüstü eğitim tez yönelimlerinin eğitim bilimleri enstitüsü düzeyinde bir analizi. International Journal of Active Learning, 3 (2), 1-10.

Özer, Ö. (2010). Disiplinlerüstü yaklaşım temelli bütünleşik eğitim programı üzerine bir durum analizi: Okul öncesi ögretmenlerinin görüşleri. Yayınlanmamış Yüksek Lisans Tezi. Orta Doğu Teknik Üniversitesi, Sosyal Bilimler Enstitüsü, Ankara.

Özkan, K. (2013). Okul öncesi öğretmenlerinin çocuk hakları konusundaki görüşlerinin belirlenmesi. Yayınlanmamış Yüksek Lisans Tezi. Çanakkale Onsekiz Mart Üniversitesi, Eğitim Bilimleri Enstitüsü, Çanakkale.

Özkanoğlu, Ö. (2015). Okul öncesi öğretmenlerinin ilk yıllar programında farklılaştırılmış öğretim hakkında görüş ve uygulamaları. Yayınlanmamış Doktora Tezi. Orta Doğu Teknik Üniversitesi, Sosyal Bilimler Enstitüsü, Ankara.

Özmen, E. (2010). İzmir ilinde kaynaştırma öğrencileri ile çalışan okul öncesi öğretmenlerinin empatik eğilimleri ile tükenmişlik düzeyleri arasındaki ilişskinin belirlenmesi. Yayınlanmamış Yüksek Lisans Tezi. Dokuz Eylül Üniversitesi, Eğitim Bilimleri Enstitüsü, İzmir.

Öztürk, E. (2010). Okul öncesi ögretmenlerinin fen ve sanat etkinliklerinin bütünleştirilmesi konusundaki bakış açıları ve deneyimlerindeki değişikliklerin incelenmesi: Durum çalışması. Yayınlanmamış Doktora Tezi. Orta Doğu Teknik Üniversitesi, Sosyal Bilimler Enstitüsü, Ankara.

Parlak Rakap, A. (2011). Okul öncesi ögretmenlerinin çocuklarda öz-disiplin gelişimine ilişkin algıları. Yayınlanmamış Doktora Tezi. Orta Doğu Teknik Üniversitesi, Sosyal Bilimler Enstitüsü, Ankara.

Parlakyıldız, B. ve Yıldızbaş, F. (2004). Okulöncesi eğitimde öğretmenlerin okuma yazmaya hazırlı çalışmalarına yönelik uygulamalarının ve görüşlerinin değerlendirilmesi. XIII. Ulusal Eğitim Bilimleri Kurultayında sunulan bildiri, (6-9 Temmuz, Malatya). 
Pasl1, H. (2017). Okul öncesi öğretmenlerinin iletişimci biçimleri ile çocukların sosyal beceri ve davranışları arasındaki iliş̧kinin incelenmesi. Yayınlanmamış Yüksek Lisans Tezi. Gazi Üniversitesi, Eğitim Bilimleri Enstitüsü, Ankara.

Resmi Gazete, (2011). 652 Sayılı Millî Eğitim Bakanlı̆̆ının Teşkilat ve Görevleri Hakkında Kanun Hükmünde Kararname, http://www.resmigazete.gov.tr/eskiler/2011/09/20110914-1.htm Erişim tarihi: 12.01.2018.

Saıran M. R. M. (2017). Okul öncesi öğretmenlerinin mesleki tükenmişlik düzeyleri ile örgütsel sinizm tutumları arasındaki ilişkinin incelenmesi. Yayınlanmamış Yüksek Lisans Tezi. Yüzüncü Yıl Üniversitesi, Eğitim Bilimleri Enstitüsü, Van.

Sak, R. (2013). Türk okul öncesi öğretmenlerinin çocuk merkezli eğitim hakkındaki inanış ve uygulamaları. Yayınlanmamış Doktora Tezi. Orta Doğu Teknik Üniversitesi, Sosyal Bilimler Enstitüsü, Ankara.

Sakarya, S. (2010). Çevreye karşı motivasyon ölçeğinin okul öncesi ögretmen adayları üzerinde geçerlik güvenirlik çalışması (Ankara ili örneği). Yayınlanmamış Yüksek Lisans Tezi. Gazi Üniversitesi, Eğitim Bilimleri Enstitüsü, Ankara.

Sarı, K. (2016). Okul öncesi ögretmenlerinin çocuk sevgilerinin ve mesleki benlik saygılarının profesyonellik değişkenleri açısından incelenmesi. Yayınlanmamış Yüksek Lisans Tezi. Necmettin Erbakan Üniversitesi, Eğitim Bilimleri Enstitüsü, Konya.

Sarıbaş, A. K. (2013). Okul öncesi öğretmenlerinin çocuk istismarına yönelik farkındalıklarının belirlenmesi. Yayınlanmamış Yüksek Lisans Tezi. Çanakkale Onsekiz Mart Üniversitesi, Eğitim Bilimleri Enstitüsü, Çanakkale.

Secer, D., Ay, D., Ozan, C. ve Yılmaz, B. Y. (2014). Rehberlik ve psikolojik danışma alanındaki araştırma eğilimleri: Bir içerik analizi. Turkish Psychological Counseling and Guidance Journal, 5 (41), 49-60

Serençelik, G. (2016). Okul öncesi öğretmenlerinin okul yönetimine katılımlarının incelenmesi. Yayınlanmamış Yüksek Lisans Tezi. İstanbul Aydın Üniversitesi, Sosyal Bilimler Enstitüsü, İstanbul.

Sesli, S. (2013). Okul öncesi öğretmenlerinin problem çözme becerileri ile disiplin anlayışlarının incelenmesi. Yayınlanmamış Yüksek Lisans Tezi. Erciyes Üniversitesi, Eğitim Bilimleri Enstitüsü, Kayseri.

Sezer Soydemir, Ş. (2011). Okul öncesi ögretmen ve ebeveynlerinin birbirlerini ve okul öncesi çocuklarını nasıl algıladıklarının metaforlar yoluyla incelenmesi. Yayınlanmamış Yüksek Lisans Tezi. Selçuk Üniversitesi, Eğitim Bilimleri Enstitüsü, Konya.

Sezer, C. (2010). Okul öncesi öğretmenlerinin ölçme değerlendirmeyi kullanma düzeylerinin belirlenmesi. Yayınlanmamış Yüksek Lisans Tezi. Çanakkale Onsekiz Mart Üniversitesi, Sosyal Bilimler Enstitüsü, Çanakkale.

Sicim, B. (2011). Okula hazırbulunuşluk: okul öncesi öğretmen adaylarının ilköğretime hazırlık ve ilkögretim programları dersinden sonra görüşlerindeki farklıllklar. Yayınlanmamış Yüksek Lisans Tezi. Orta Doğu Teknik Üniversitesi, Sosyal Bilimler Enstitüsü, Ankara.

Süngü, D. (2012). Okul öncesi öğretmenlerinin hizmet içi eğitim hakkındaki görüşlerinin çeşitli değişkenler açısından incelenmesi (Adıyaman ili örneği). Yayınlanmamış Yüksek Lisans Tezi. Necmettin Erbakan Üniversitesi, Eğitim Bilimleri Enstitüsü, Konya. 
Şahin, E. (2005). Okul öncesi eğitimi öğretmen adayları ve öğretmenleri için uygulama kılavuzu. Ankara: An1 Yayıncilik.

Şahin, İ. T. (2013). Okul öncesi ögretmenlerinin gelişime uygun sınıf yönetimi ile ilgili inanıs ve uygulamaları. Yayınlanmamış Doktora Tezi. Orta Doğu Teknik Üniversitesi, Sosyal Bilimler Enstitüsü, Ankara.

Şahin, M. (2014). Okul öncesi öğretmenlerinin ölçme ve değerlendirme hakkındaki düşünce ve uygulamaları. Yayınlanmamış Yüksek Lisans Tezi. Çanakkale Onsekiz Mart Üniversitesi, Eğitim Bilimleri Enstitüsü, Çanakkale.

Şahin, M., Göğebakan Yıldız, D. ve Duman, R. (2011). Türkiye'deki sosyal bilgiler eğitimi tezleri üzerine bir değerlendirme. Sosyal Bilgiler Eğitimi Araştırmaları Dergisi, 2 (2), 96-121.

Şahiner, V. N. (2013). Okul öncesi ögretmenlerinin anasınıflarında okuma-yazma ögretimi konusundaki görüşlerinin araştırılması: İstanbul ili; Şişli ilçesi örneği. Yayınlanmamış Yüksek Lisans Tezi. Yeditepe Üniversitesi, Sosyal Bilimler Enstitüsü, İstanbul.

Şeker, P. T. (2013). Okul öncesi öğretmenlerinin matematik eğitimine yönelik inanç ve öz yeterliklerinin 48-60 aylık çocukların matematik becerileri üzerine etkisinin incelenmesi. Yayınlanmamış Doktora Tezi. Gazi Üniversitesi, Eğitim Bilimleri Enstitüsü, Ankara.

Şen, B. (2011). Okul öncesi ögretmenlerinin mesleki doyumları ve hizmet içi eğitim ihtiyaçları üzerine bir araştırma (Uşak ili örneği). Yayınlanmamış Yüksek Lisans Tezi. Selçuk Üniversitesi, Sosyal Bilimler Enstitüsü, Konya.

Şen, Ş. G. Erişen, Y. (2002). Öğretmen yetiştiren kurumlarda öğretim elemanlarının etkili öğretmenlik özellikleri. Gazi Üniversitesi Gazi Eğitim Fakültesi Dergisi, 22(1), 99-116.

Şenay, T. (2017). Okul öncesi öğretmenlerinin yöneticilerinde alglladıkları öğretimsel liderlik davranışı ve örgütsel bağlllıkları arasındaki ilişki. Yayınlanmamış Yüksek Lisans Tezi. Çanakkale Onsekiz Mart Üniversitesi, Eğitim Bilimleri Enstitüsü, Çanakkale.

Şenel, E. (2014). Okul öncesi ögretmenlerinde öz yeterlik algısının tükenmişlik düzeyini yordama gücü: Denizli ili örneği. Yayınlanmamış Yüksek Lisans Tezi. Pamukkale Üniversitesi, Eğitim Bilimleri Enstitüsü, Denizli.

Şenol, F. B. (2012). Okul öncesi ögretmen adayları ile okul öncesi ögretmenlerinin ögretmenlik mesleğine yönelik öz yeterlik inançlarının karşılaş̧tırılması. Yayınlanmamış Yüksek Lisans Tezi. Afyon Kocatepe Üniversitesi, Sosyal Bilimler Enstitüsü, Afyon.

Tarman, B., Acun, İ. ve Yüksel, Z. (2010). Sosyal bilimler alanındaki tezlerin değerlendirilmesi. Gaziantep Üniversitesi Sosyal Bilimler Dergisi. 9(3), 725-746.

Taştepe, T., Öztürk Serter, G., Yurdakul, Y., Taygur Altıntaş, T. ve Bütün Ayhan, A. (2016). Türkiye'de okul öncesi dönemde kaynaştırma konusunda yapılan lisansüstü tezlerin incelenmesi. International Journal of Social Science, 49, 501-514.

Tatlı, S. ve Adıgüzel, O. C. (2012). Türkiye'deki lisansüstü karşılaştırmalı eğitim tezlerinin çok boyutlu bir incelemesi. Anadolu Üniversitesi Sosyal Bilimler Dergisi. 12 (1), 143-150.

Tekmen, B. (2012). Okul öncesi öğretmenliği programının akademisyenlerin bakış açısıyla değerlendirilmesi. Yayınlanmamış Doktora Tezi. Orta Doğu Teknik Üniversitesi, Sosyal Bilimler Enstitüsü, Ankara. 
Tepebağ, D. (2017). Okul öncesi ögretmenlerinin okul bahçesini eğitsel amaçlı kullanımına yönelik görüşlerinin incelenmesi. Yayınlanmamış Yüksek Lisans Tezi. Çukurova Üniversitesi, Sosyal Bilimler Enstitüsü, Adana.

Tezcan, F. (2012). Okul öncesi öğretmenlerinin erken yaştaki üstün zekâlı çocuklara ve eğitimlerine yönelik algıları. Yayınlanmamış Yüksek Lisans Tezi. Orta Doğu Teknik Üniversitesi, Sosyal Bilimler Enstitüsü, Ankara.

Tezcan, T. (2011). Okul öncesi ögretmenlerinin yaşam kalitesi ve iş doyumlarının bazı değişkenler açısından incelenmesi (Bolu ili örneği). Yayınlanmamış Yüksek Lisans Tezi. Abant İzzet Baysal Üniversitesi, Sosyal Bilimler Enstitüsü, Bolu.

Topaloğlu, A. Ö. (2009). Okul öncesi eğitim kurumlarında çalışan yöneticilerin örgütsel amaçları gerçekleştirmedeki yeterlilikleri. Yayınlanmamış Yüksek Lisans Tezi. Trakya Üniversitesi, Sosyal Bilimler Enstitüsü, Edirne.

Toyran, G. (2015). Okul öncesi öğretmen adaylarının yaratıcı düşünme düzeylerinin ve eleştirel düşünme eğilimlerinin bazı değişkenler açısından incelenmesi. Yayınlanmamıș Yüksek Lisans Tezi. Dokuz Eylül Üniversitesi, Eğitim Bilimleri Enstitüsü, İzmir.

Tuna, D. M. (2015). Sinıfinda özel gereksinimli ögrencisi olan okul öncesi ögrretmenlerinin doğal ögretim sürecine ilişkin bakış açılarının incelenmesi. Yayınlanmamış Yüksek Lisans Tezi. Anadolu Üniversitesi, Eğitim Bilimleri Enstitüsü, Eskişehir.

Türkdemir, A. (2013). Okul öncesi öğretmenlerinin bakış açısından okul öncesi eğitim denetiminin değerlendirilmesi. Yayınlanmamış Yüksek Lisans Tezi. Mersin Üniversitesi, Eğitim Bilimleri Enstitüsü, Mersin.

Türkeç Aktaş, Y. (2012). Okul öncesi ögretmenlerinin yeterlilik düzeyleri. Yayınlanmamış Yüksek Lisans Tezi. Adnan Menderes Üniversitesi, Sosyal Bilimler Enstitüsü, Aydın.

Uçar, N. (2011). Müziğin çocuk gelişimi üzerindeki etkisinin okul öncesi öğretmenlerinin demografik farklılıklarına göre incelenmesi. Yayınlanmamış Yüksek Lisans Tezi. Atatürk Üniversitesi, Eğitim Bilimleri Enstitüsü, Erzurum.

Uçar, N. Y. (2010). Okul öncesi öğretmenlerinin sosyal becerilerini etkileyen faktörler. Yayınlanmamış Yüksek Lisans Tezi. Selçuk Üniversitesi, Eğitim Bilimleri Enstitüsü, Konya.

Ural, O. ve Ramazan, M. O. (2007), Türkiye'de okul öncesi eğitimin dünü ve bugünü, Türkiye'de okul öncesi eğitim ve ilköğretim sistemi temel sorunlar ve çözüm önerileri (Ed.: S. Özdemir, H. Bacanlı ve M. Sözer), Türk Eğitim Derneği, 11-56.

Uysal, Ş. (2013). Türkiye'de eğitim yönetimi teftişi planlaması ve ekonomisi alanındaki doktora tezlerinin incelenmesi. Yayınlanmamış Doktora Tezi. Osmangazi Üniversitesi, Eğitim Bilimleri Enstitüsü, Eskişehir.

Yaşar, Ş. ve Papatğa, E. (2015). İlkokul matematik derslerine yönelik yapılan lisansüstü tezlerin incelenmesi. Trakya Üniversitesi Ĕ̈itim Fakültesi Dergisi, 5 (2), 113-124.

Yeşilyurt, F. (2018). Türkiye'de eğitim-öğretim alanında yapılan bilgisayar oyunları konulu lisansüstü tezlerin incelenmesi. OPUS Uluslararası Toplum Araştırmaları Dergisi, 9 (16), 1506-1524.

Yıldırım, A. ve Şimşek, H. (2008). Sosyal bilimlerde nitel araştırma yöntemleri. Ankara: Seçkin Yayınları. 
Yıldırım, Ö. (2016). Okul öncesi öğretmenlerinin iş doyumları ile slnıf yönetimi becerileri arasındaki ilişki: Başakşehir ve Küçükçekmece örneği. Yayınlanmamış Yüksek Lisans Tezi. İstanbul Üniversitesi, Eğitim Bilimleri Enstitüsü, İstanbul.

Yılmaz, H. (2015). Okul yöneticilerinin kişiler arast iletişim becerilerinin okul öncesi ögretmenlerinin görüşleri açısından incelenmesi. Yayınlanmamış Yüksek Lisans Tezi. Selçuk Üniversitesi, Sosyal Bilimler Enstitüsü, Konya.

Yıldız, A. (2004). Türkiye'deki yetişkin eğitimi araştırmalarına toplu bakış. Ankara Üniversitesi Eğitim Bilimleri Fakültesi Dergisi, 37 (1), 78-97.

Y1lmaz, H. (2016). Okul öncesi öğretmenlerinin öz-düzenleme düzeyleri ile kullandıkları öğretim uygulamaları düzeyleri arasındaki ilişkinin incelenmesi. Yayınlanmamış Yüksek Lisans Tezi. Marmara Üniversitesi, Eğitim Bilimleri Enstitüsü, İstanbul.

Yılmaz, N. (2011). Okul öncesi öğretmenlerinin iletişim becerileri, problem çözme becerileri ve empatik eğilim düzeyleri. Yayınlanmamış Yüksek Lisans Tezi. Muğla Sitkı Koçman Üniversitesi, Eğitim Bilimleri Enstitüsü, Muğla.

Yılmaz, N. (2013). Okul öncesi ögretmen adaylarının bireysel yenilikçilik düzeyleri ve öğretim amaçlı bilgisayar kullanımına yönelik algılanan özelliklerin araştırılması. Yayınlanmamış Yüksek Lisans Tezi. Orta Doğu Teknik Üniversitesi, Sosyal Bilimler Enstitüsü, Ankara.

Y1lmaz, S. (2011). Okul öncesi öğretmen adaylarının ve okul öncesi öğretmenlerinin erken çocukluk eğitimi döneminde yaratıcılık hakkındaki görüşleri. Yayınlanmamış Yüksek Lisans Tezi. Orta Doğu Teknik Üniversitesi, Sosyal Bilimler Enstitüsü, Ankara.

Zağlı, Ü. (2010). Sakarya ilinde görev yapan okul öncesi öğretmenlerin zihinsel engelli çocukların kaynaştırma yoluyla eğitimlerine ilişkin tutumlarının incelenmesi. Yayınlanmamış Yüksek Lisans Tezi. Gazi Üniversitesi, Eğitim Bilimleri Enstitüsü, Ankara.

Zeytun, S. (2010). Okul öncesi öğretmenliği ögrencilerinin yaratıcılık ve problem çözme düzeyleri arasındaki ilişkinin incelenmesi. Yayınlanmamış Yüksek Lisans Tezi. Dokuz Eylül Üniversitesi, Eğitim Bilimleri Enstitüsü, İzmir.

Zincirli, Ö. (2014). Okul öncesi ögretmen adaylarının anne baba tutum algısı, eleştirel düşünme ve problem çözme becerileri arasındaki ilişki. Yayınlanmamış Yüksek Lisans Tezi. Fırat Üniversitesi, Eğitim Bilimleri Enstitüsü, Elazığ.

Zoroğlu, Ö. (2014). Okul öncesi öğretmenlerinin mesleğe yönelik tutumları, mesleki benlik saygılarn ile iş doyumları arasındaki ilişki. Yayınlanmamış Yüksek Lisans Tezi. Karadeniz Teknik Üniversitesi, Eğitim Bilimleri Enstitüsü, Trabzon. 